\title{
Photosynthetic electron turnover in the tropical and subtropical Atlantic Ocean
}

\author{
David J. Suggett ${ }^{\mathrm{a}, *}$, C. Mark Moore ${ }^{\mathrm{a}, \mathrm{b}}$, Emilio Marañón ${ }^{\mathrm{c}, 1}$, Claudia Omachi ${ }^{\mathrm{d}}$, \\ Ramiro A. Varela ${ }^{\mathrm{e}}$, Jim Aiken ${ }^{\mathrm{f}}$, Patrick M. Holligan ${ }^{\mathrm{b}}$ \\ ${ }^{a}$ Department of Biological Sciences, University of Essex, Colchester, CO4 3SQ, UK \\ ${ }^{\mathrm{b}}$ National Oceanography Centre, European Way, Empress Dock, Southampton, SO14 3ZH, UK \\ ${ }^{\mathrm{c}}$ Departamento de Ecología y Biología Animal, Universidad de Vigo, 36200 Vigo, Spain \\ ${ }^{\mathrm{d} C T T M a r / U N I V A L I, ~ R u a ~ U r u g u a i, ~} 458$ Itajai, 88302-202, Brazil \\ ${ }^{\mathrm{e}}$ Universidad de Vigo, Campus Lagoas-Marcosende, 36200 Vigo, Spain \\ ${ }^{\mathrm{f}}$ Plymouth Marine Laboratory, Prospect Place, Plymouth, PL1 3DH, UK
}

Received 31 August 2005; received in revised form 20 January 2006; accepted 14 May 2006

Available online 4 August 2006

\begin{abstract}
Photosynthetic electron transport directly generates the energy required for carbon fixation and thus underlies the aerobic metabolism of aquatic systems. We determined photosynthetic electron turnover rates, ETRs, from ca. 100 FRR fluorescence water-column profiles throughout the subtropical and tropical Atlantic during six Atlantic Meridional Transect cruises (AMT 6, May-June 1998, to AMT 11, September-October 2000). Each FRR fluorescence profile yielded a water-column ETR-light response from which the maximum electron turnover rate $\left(\mathrm{ETR}_{\mathrm{RCII}}^{\mathrm{max}}\right)$, effective absorption $\left(\sigma_{\mathrm{PSII}}\right)$ and light saturation parameter $\left(E_{\mathrm{k}}\right)$ specific to the concentration of photosystem II reaction centres (RCIIs) were calculated. $\mathrm{ETR}_{\mathrm{RCII}}^{\max }$ and $E_{\mathrm{k}}$ increased whilst $\sigma_{\mathrm{PSII}}$ decreased with mixed-layer depth and the daily integrated photosynthetically active photon flux when all provinces were considered together. These trends suggested that variability in maximum ETR can be partly attributed to changes in effective absorption. Independent bio-optical measurements taken during AMT 11 demonstrated that $\sigma_{\mathrm{PSII}}$ variability reflects taxonomic and physiological differences in the phytoplankton communities. $\mathrm{ETR}_{\mathrm{RCII}}^{\max }$ and $E_{\mathrm{k}}$, but not $\sigma_{\mathrm{PSII}}$, remained correlated with mixed-layer depth and daily integrated photosynthetically active photon flux when data from each oceanic province were considered separately, indicating a decoupling of electron turnover and carbon fixation rates within each province. Comparison of maximum ETRs with ${ }^{14} \mathrm{C}$-based measurements of $P^{\max }$ further suggests that light absorption and $\mathrm{C}$ fixation are coupled to differing extents for the various oligotrophic Atlantic provinces. We explore the importance of quantifying RCII concentration for determination of ETRs and interpretation of ETR-C fixation coupling.
\end{abstract}

(C) 2006 Elsevier Ltd. All rights reserved.

Keywords: AMT; Subtropical gyres; Tropical equatorial; Phytoplankton; Fast Repetition Rate fluorometry; Photosynthetic electron turnover

\footnotetext{
*Corresponding author.

E-mail address: dsuggett@essex.ac.uk (D.J. Suggett).

${ }^{1}$ Present address: Laboratoire d'Océanographie de Villefranche, CNRS -UPMC, 06234 Villefranche-sur-Mer, France.
} 


\section{Introduction}

Routine oceanographic measurements of primary productivity trace the evolution of $\mathrm{O}_{2}$ or assimilation of inorganic carbon $\left(\mathrm{C}_{\mathrm{i}}\right)$ or nitrogen. Fluxes of these elements between phytoplankton and their surrounding environment indicate the net community metabolism and thus the trophic structure of the food web and significance of carbon sequestration (Karl et al., 1998; Serret et al., 2001; González et al., 2002). Furthermore, the light-response of these productivity measurements describe the physiological status of photoautrophic communities that then can be applied to models investigating environmental change (Sathyendranath et al., 1995; Marañón and Holligan, 1999). Consequently, considerable effort has been made in recent years to characterise $\mathrm{O}_{2}$ evolution and $\mathrm{C}_{\mathrm{i}}$ assimilation in the large and vastly under-sampled oceanic tropical and subtropical regions (Karl et al., 1998; Marañón et al., 2000; Serret et al., 2001; González et al., 2002; Marañón, 2005).

Autotrophic $\mathrm{O}_{2}$ evolution and $\mathrm{C}_{\mathrm{i}}$ assimilation are governed by the rate of electron turnover by the photochemical 'light' reactions (Allen, 2002; Behrenfeld et al., 2004; Kramer et al., 2004). Absorbed light energy promotes the splitting of water to release $\mathrm{O}_{2}$, protons and electrons. Each electron is transferred between a series of redox molecules to provide the reductant used to fix $\mathrm{CO}_{2}$ into organic matter. Electron transfer also results in the accumulation of protons within the lumen of the thylakoid membranes. A gradient of protons across the thylakoid membranes drives synthesis of ATP via ATP synthase. ATP is then used to fix $C_{i}$ but is also consumed by additional energy-demanding processes that are crucial for the maintenance and regulation of photochemical pathways, in particular uptake and assimilation of nutrients including $\mathrm{C}_{\mathrm{i}}$ (Falkowski and Raven, 1997; Allen, 2002; Kramer et al., 2004). ATP also can be provided by respiration (Badger et al., 2000; Geider and MacIntyre, 2002) but at the expense of previously fixed carbon. Therefore, characterising the variability of electron turnover rates can potentially provide a more detailed understanding of the role of primary productivity upon aquatic community metabolism than simply tracing $\mathrm{C}_{\mathrm{i}}$ or $\mathrm{O}_{2}$.

Electron turnover rates (ETRs, linear $\mathrm{e}^{-}$turnover per unit biomass per unit time) of microalgae can be determined using chlorophyll $a$ fluorescence induction techniques (Gorbunov et al., 2001; Kromkamp and Forster, 2003; Suggett et al., 2003). One such induction technique, Fast Repetition Rate (FRR) fluorescence (Kolber et al., 1998), has become widely used by oceanographers as it avoids the need to incubate discrete water samples and is highly sensitive. However, despite these benefits, relatively few FRR fluorescence-based measurements of marine primary productivity have been reported (Suggett et al., 2001; Moore et al., 2003; Raateoja et al., 2004; Smyth et al., 2004) and little is known of the variability of ETRs in oligotrophic subtropical and tropical oceanic environments.

Two main limitations account for the previous sparsity of FRR-based information. Firstly, it has been problematic to reconcile FRR determinations of ETR with conventional $\mathrm{O}_{2}$ evolution or $\mathrm{C}$ uptake productivity measurements (Suggett et al., 2003; Raateoja et al., 2004). ETRs are a direct measure of the potential to split water and hence of $\mathrm{O}_{2}$ production, provided that the maximum quantum yield of $\mathrm{O}_{2}$ evolution remains unchanged (Kromkamp and Forster, 2003). Two electron cycling processes act to decouple ETR from net $\mathrm{O}_{2}$ evolution, cycling of electrons around photosystem II (PSII) and reduction of $\mathrm{O}_{2}$ by the Mehler reaction (Badger et al., 2000). Both PSII electron cycling (Prášil et al., 1996) and the Mehler reaction (Kana, 1992; Lewitus and Kana, 1995) occur under exposure to intense light. In addition, the Mehler reaction is particularly pronounced in cyanophytes (Kana, 1992; Lewitus and Kana, 1995). As such, derivations of net $\mathrm{O}_{2}$ from FRR-based ETRs may be particularly problematic in the intense light, cyanobacterial-dominated communities that are typical of many subtropical and tropical marine environments. Secondly, direct FRR-based measurements alone are not enough to accurately quantify volume-specific photoautotrophic productivity rates since they are weighted to the excitation wavelength that is employed and to the number of functional photosystem II (PSII) reaction centres (RCII) (Suggett et al., 2001, 2003). FRR-based calculations of productivity that are weighted to the RCII concentration are not problematic per se. However, without specific knowledge of the RCII concentration, such calculations are incomparable with 'conventional' productivity measurements that are typically weighted on a per unit algal pigment, per cell or per unit volume of seawater basis.

In addition to $\mathrm{O}_{2}$ evolution, photosynthetic linear electron turnover drives protonation of the thylakoid lumen that is then available for ATP synthesis. 
Therefore, we can re-define FRR-based 'productivity' more accurately as the energetic potential available for all photosynthetic pathways. Also, we can correct for the spectral weighting of FRRexcitation (Babin et al., 1996; Suggett et al., 2001; Raateoja et al., 2004) and obtain some knowledge of the RCII concentration indirectly (Suggett et al., 2001, 2004; Moore et al., 2005) provided additional bio-optical and/or biophysical properties of the PSII antenna-reaction centre complex are measured.

Here we employed FRR fluorometry to determine the RCII normalised rate of electron turnover $\left(\mathrm{ETR}_{\mathrm{RCII}}\right)$, and hence energetic potential for photosynthesis, by phytoplankton communities throughout the subtropical and tropical Atlantic Ocean. Water-column profiles of FRR fluorescence and ETR $_{\mathrm{RCII}}$ were used to derive maximum rates of effective absorption, $\sigma_{\text {PSII }}(\max )$, and photosynthetic electron turnover, $\mathrm{ETR}_{\mathrm{RCII}}^{\max }$, from six (ca. 100 casts) Atlantic Meridional Transects. Considerable variability of both $\sigma_{\mathrm{PSII}}(\max )$ and $\mathrm{ETR}_{\mathrm{RCII}}^{\max }$ was observed between and within subtropical and tropical provinces throughout the sampling period. We discuss the underlying mechanisms that may account for this variability. Also, we consider the importance of quantifying RCII concentrations for determining chlorophyll- or volume-normalised ETRs and for interpreting the coupling between electron turnover and carbon fixation for these subtropical and tropical provinces.

\section{Methods}

\subsection{Sampling and instrument deployment}

Data were collected during Atlantic Meridional Transect (AMT) cruises 7-11 between Grimsby (UK) and Montevideo (Uruguay), September 1998-October 2000 (Table 1, Fig. 1). Cruise transects 7, 9 and 10 followed a similar track between northern and southern subtropical gyres via the western tropical Atlantic. In contrast, transects 8 and 11 followed a route between northern and southern subtropical gyres via Ascension Island and hence through the eastern tropical Atlantic. Some data from AMT6 between Cape Town (South Africa) and Grimsby (UK), MayJune 1998, are also included. Data from all six cruises were separated into four Atlantic biogeographical provinces (Table 1): the northern subtropical gyre-east $\left(\mathrm{NSTG}, 22-40^{\circ} \mathrm{N}\right)$, the northern tropical $\left(\mathrm{NT}, 6-22^{\circ} \mathrm{N}\right)$, the eastern and western tropical (ET, $16^{\circ} \mathrm{S}-06^{\circ} \mathrm{N}, \quad 20^{\circ} \mathrm{W}-20^{\circ} \mathrm{E}$; WT, $\left.16^{\circ} \mathrm{S}-06^{\circ} \mathrm{N}, 20-60^{\circ} \mathrm{W}\right)$, and the southern subtropical gyre (SSTG, $16-35^{\circ} \mathrm{S}$ ).

A Seabird $911+$ CTD-Niskin rosette system and Plymouth Marine Laboratory-designed optical rig were each deployed at least once per day and to depths of $200-250 \mathrm{~m}$. A Chelsea Instruments FAST ${ }^{\text {tracka }}$ FRR fluorometer with integrated $2 \pi$ photosynthetically available radiation (PAR,

Table 1

Number of FRR fluorescence casts with sampling dates and locations for Atlantic Meridional Transects (AMTs) 6-11

\begin{tabular}{|c|c|c|c|c|c|c|}
\hline AMT Cruise & 6 & 8 & 10 & 7 & 9 & 11 \\
\hline Sample dates & 14th May-12th & 3rd May-31st & 15th April-2nd & 16th Sept-14th & 22nd Sept-12th & 15th Sept -9 th \\
\hline$(\mathrm{FRRF})$ & June 1998 & May 1999 & May 2000 & Oct 1998 & Oct 1999 & Oct 2000 \\
\hline Sample seasons & \multicolumn{3}{|c|}{ Austral autumn, Boreal spring } & \multicolumn{3}{|c|}{ Austral spring, Boreal autumn } \\
\hline $\begin{array}{l}\text { NSTG }\left(22-40^{\circ} \mathrm{N}\right. \\
\left.15-25^{\circ} \mathrm{W}\right)\end{array}$ & 2 & 4 & 4 & 5 & 4 & 4 \\
\hline $\begin{array}{l}\text { NT }\left(6-22^{\circ} \mathrm{N}\right. \\
\left.15-25^{\circ} \mathrm{W}\right)\end{array}$ & 3 & 4 & 2 & 4 & 4 & 3 \\
\hline $\begin{array}{l}\mathrm{ET}\left(16^{\circ} \mathrm{S}-06^{\circ} \mathrm{N}\right. \\
\left.20^{\circ} \mathrm{W}-10^{\circ} \mathrm{E}\right)\end{array}$ & 7 & 4 & & & & 7 \\
\hline $\begin{array}{l}\mathrm{WT}\left(16^{\circ} \mathrm{S}-06^{\circ} \mathrm{N}\right. \\
\left.20-50^{\circ} \mathrm{W}\right)\end{array}$ & & & 4 & 4 & 3 & \\
\hline $\begin{array}{l}\text { SSTG }\left(16-35^{\circ} \mathrm{S}\right. \\
\left.20-50^{\circ} \mathrm{W}\right)\end{array}$ & & 7 & 4 & 3 & 6 & 7 \\
\hline $\begin{array}{l}\text { BENG }\left(16-35^{\circ} \mathrm{S}\right. \\
\left.10-20^{\circ} \mathrm{E}\right)\end{array}$ & 9 & & & & & \\
\hline
\end{tabular}

Cruises are separated into 'northbound' (6, 8 and 10) and 'southbound' (7, 9 and 11). Open ocean tropical and subtropical provinces are modified from Longhurst et al. (1995), NSTG (north Atlantic subtropical gyre-east), NT (northern tropical Atlantic), ET (eastern Tropical Atlantic), WT (western tropical Atlantic) and SSTG (south Atlantic subtropical gyre). The BENG (Benguela coastal upwelling) was also sampled during AMT 6 but is not included in the data analyses here. 


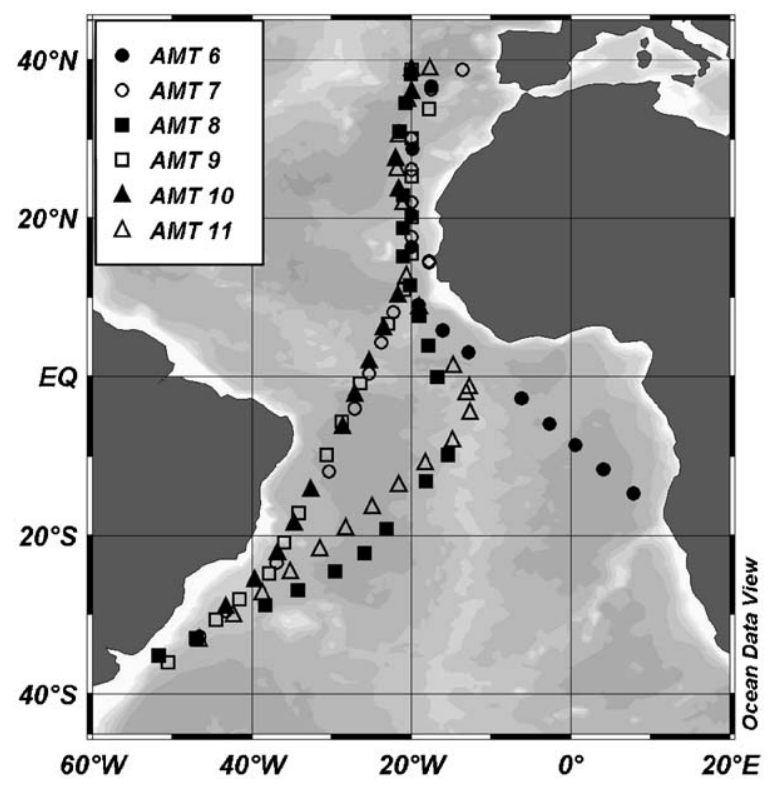

Fig. 1. Sampling locations of Fast Repetition Rate (FRR) fluorescence casts in the tropical and subtropical Atlantic during AMTs 6-11.

$400-700 \mathrm{~nm}$ irradiance) and pressure sensors was fastened to the frame of the CTD-rosette during AMTs 6-10 or integrated with the optical rig during AMT 11. Both the FRR fluorometer and PAR sensor were attached in such a way as to avoid shadowing from other instruments. These instrument packages were then deployed at approximately local noon time from the sunward side of the ship. Depths for collection of water samples using Niskin bottles were determined from the downward temperature and salinity profiles. Incident PAR was measured continuously and integrated to give the along track daily integrated photosynthetically active photon flux density (PPFD).

Additional daily pre-dawn CTD casts also were preformed throughout AMT 11. Simultaneous optical and FRR fluorescence profiles were not made. Instead, discrete water samples were immediately drawn from the rosette and passed through the enclosed chamber of the FRR fluorometer and thus yielded discrete dark-adapted fluorescence measurements.

\subsection{Light absorption, pigments and optics}

Bio-optical measurements were made from water collected from the local noon casts during AMT 11 only. 1.5-3 L were filtered through $25 \mathrm{~mm}$ Whatman
$\mathrm{GF} / \mathrm{F}$ filters and stored at $-80{ }^{\circ} \mathrm{C}$ for onboard measurements of particulate light absorption or within liquid $\mathrm{N}_{2}$ for HPLC analysis of phytoplankton pigments upon return. Total particulate matter absorption spectra were measured on the GF/F filters mounted on an opal glass support using a single beam Beckman DU650 scanning $(\lambda, 1-\mathrm{nm}$ intervals between 350 and $750 \mathrm{~nm}$ ) spectrophotometer. A separate $\mathrm{GF} / \mathrm{F}$ was soaked in filtered seawater and used as a blank. Phytoplankton absorption on the filters, $a(\lambda)\left(\mathrm{m}^{-1}\right)$, was determined as described previously (Suggett et al., 2001),

$a(\lambda)=\frac{2.303 \mathrm{OD}(\lambda) S}{\beta(\lambda) V}$,

where OD $(\lambda)$ is the optical density of all particulate material retained on the filter minus that at $750 \mathrm{~nm}$, $V$ is the volume of filtered seawater $\left(\mathrm{m}^{3}\right)$, and $S$ is the particulate retention area of the GF/F filter measured using the spectrophotometer $\left(\mathrm{m}^{2}\right) . \beta(\lambda)$ is the pathlength amplification factor and was estimated as

$\beta(\lambda)=1.63 \mathrm{OD}(\lambda)^{-0.22}$.

Contribution of light absorption by particulate detritus $a_{\mathrm{d}}(\lambda)$ upon $a(\lambda)$ was determined numerically following the method of Bricaud and Stramski (1990) improved for low detritus content (Varela et al., 1998).

Concentrations of both 'photosynthetically active' (PS, mono- and di-vinyl chlorophylls $a$ and $b$, chlorophyll $c$, Peridinin, fucoxanthin, 19'-hexanoyloxyfucoxanthin, 19'-butanoyloxyfucoxanthin and prasinoxanthin) and 'non-photosynthetically active', or 'photoprotective' (PP, violaxanthin, diadinoxanthin, alloxanthin, lutein, zeaxanthin and $\beta$-carotene) pigments were determined using a Thermo Separations product HPLC as described previously (Barlow et al., 2002).

Underwater optical spectra at depths corresponding with particulate absorption and pigment samples were determined from irradiance and radiance measured at seven wavelengths $(412,443,490,510$, 555, 620 and $670 \mathrm{~nm}$ ) (Satlantic multispectral optical sensors, Satlantic Inc., Canada). To obtain spectrally resolved in situ light between 400 and $700 \mathrm{~nm}$, in situ wavelengths were interpolated nonlinearly following the shape of a global climatological spectrum as described previously (Suggett et al., 2001). 


\subsection{FRR fluorescence and determination of electron transport rates}

Throughout all cruises, the FRR fluorometer was programmed to deliver and record single photochemical turnover excitation and emission sequences as described by Moore et al. (2003, 2005) and Suggett et al. (2003, 2004). Specifically, saturating-chain sequences of $1001.1 \mu$ s flashes were applied at $2.8 \mu \mathrm{s}$ intervals. Fluorescence transients were logged internally during profiling from the average of 16 of these sequences delivered in succession. This data acquisition protocol was then alternated between the 'open' and 'enclosed' FRR chambers at an interval of $30 \mathrm{~ms}$. The gain was set prior to deployment according to that employed by a second FAST ${ }^{\text {tracka }}$ FRR fluorometer on 'autogain' plumbed into the underway non-toxic surface seawater supply. Any data that exhibited saturation of the FRR photomultiplier tube were excluded from further analyses. Discrete samples from the pre-dawn casts during AMT 11 were held in the 'enclosed' chamber and exposed to 50 individual sequences each separated by 1-s intervals. These 50 acquisitions were logged internally and subsequently averaged into a single, high signal: noise transient (see Suggett et al., 2004). Similarly, all logged fluorescence transients from each vertical cast per station were averaged into $5-10 \mathrm{~m}$ depth bins to increase the signal to noise ratio. Fluorescence transients were finally fitted to the biophysical model of Kolber et al. (1998) using 'v4' software (Laney, 2003) to yield values of minimum and maximum fluorescence $\left(F_{\min }, F_{\max }\right)$ and the effective absorption cross section $\left(\sigma_{\mathrm{PSII}}\right)$.

Obtaining accurate absolute values of biophysical parameters from the fluorescence transients requires the subtraction of both instrument response function (IRF) non-linearities (Laney, 2003) and, depending on the parameter, sample blanks (Cullen and Davis, 2003). An IRF was only determined following the final cruise, AMT 11 using a chlorophyll $a$ extract and deionised water (Laney, 2003; Suggett et al., 2004; Moore et al., 2005) for all gains and both FRR chambers. We subsequently applied this IRF to fluorescence transients obtained from all prior cruises. Sample blanks were not taken throughout AMTs 6-11. Instead, we used an approach for calculating electron transport rates ETR that is independent of the need for sample blanks. Our approach is based on that of Gorbunov et al. (2001) and uses only two parameters easily obtained from FRR fluorometry in situ under actinic light, the PSII effective absorption cross section, $\sigma_{\text {PSII }}{ }^{\prime}\left(\AA^{2}\right.$ quanta $\left.^{-1}\right)$, and PSII trapping efficiency of excitons $\left(F_{\mathrm{q}}{ }^{\prime} / F_{\mathrm{v}}{ }^{\prime}\right.$, dimensionless $)$, in addition to the PPFD,

$\mathrm{ETR}_{\mathrm{RCII}}=\mathrm{PPFD} \sigma_{\mathrm{PSII}^{\prime}} F_{\mathrm{q}}^{\prime} / F_{v}^{\prime} 0.006023$,

where $\mathrm{ETR}_{\mathrm{RCII}}$ is the rate of electron turnover normalised to the number of PSII reaction centres $\left(\mathrm{mole}^{-} \mathrm{mol} \mathrm{RCII}^{-1} \mathrm{~s}^{-1}\right.$ ) and 0.006023 is a factor that accounts for the conversion of $\sigma_{\mathrm{PSII}}{ }^{\prime}$ from $\AA^{2}$ quanta $^{-1}$ to $\mathrm{m}^{2} \mathrm{~mol} \mathrm{RCII}{ }^{-1}$ and of PPFD from $\mu$ mol photons $\mathrm{m}^{-2} \mathrm{~s}^{-1}$ to mol photons $\mathrm{m}^{-2} \mathrm{~s}^{-1}$. Here, $F_{\mathrm{q}}{ }^{\prime} / F_{\mathrm{v}}{ }^{\prime}$ is estimated as the ratio of $\left(F_{\max }-\right.$ $\left.F_{\min }\right) / F_{\min }$ from the 'open' and 'enclosed' chambers,

$F_{\mathrm{q}}^{\prime} / F_{\mathrm{v}}^{\prime}=\frac{\left(F_{\max }-F_{\min }\right) /\left(F_{\max }-f\right)^{\text {OPEN chamber }}}{\left(F_{\max }-F_{\min }\right) /\left(F_{\max }-f\right)^{\text {ENCLOSED chamber }}}$.

The proportion of "non-active" fluorescence $(f$, the sample blank) inherent to fluorescence yield measurements cancel in Eq. (4). However, this calculation of $F_{\mathrm{q}}{ }^{\prime} / F_{\mathrm{v}}{ }^{\prime}$ makes two assumptions: (1) the two FRR chambers are directly comparable and (2) that the brief period of time within the FRR enclosed chamber allows for total $Q_{\mathrm{A}}$ reoxidation. We have confidence that the first assumption was met since the two chambers yielded the same fluorescence yields at depths where non-photochemical quenching was absent (data not shown). However, the second assumption may not always be met because slow $Q_{\mathrm{A}}$ reoxidation may occur without supplementary far red light, which is not provided by the FAST ${ }^{\text {tracka }}$ FRR fluorometer.

Direct in situ FRR measurements of $\sigma_{\text {PSII }}$ are weighted to the LED spectrum of the FRR fluorometer (termed $\sigma_{\text {PSII }}{ }^{\prime} 478$, Moore et al., 2006, and references therein). Accurate application of Eq. (3) in situ requires that $\sigma_{\text {PSII }}^{\prime}, 478$ be adjusted to the spectrum of light that phytoplankton receive in situ, $\sigma_{\text {PSII }}{ }^{\prime}$,in situ. Therefore, effective absorption coefficients, $\bar{a}\left(\mathrm{~m}^{-1}\right)$, were determined from spectrally resolved particulate absorption, $a\left(\mathrm{~m}^{-1}\right)$, and excitation by the FRR fluorometer LEDs or by the light field in situ (PPFD $(\lambda), \mu \mathrm{mol} \mathrm{m}{ }^{-2} \mathrm{~s}^{-1} \mathrm{~nm}^{-1}$ ),

$$
\begin{aligned}
& \bar{a}(\lambda)(z) \\
& \quad=\left(\sum_{400}^{700} a(\lambda)(z) \operatorname{PPFD}(\lambda)(z)\right) / \sum_{400}^{700} \operatorname{PPFD}(\lambda)(z)
\end{aligned}
$$


FRR effective absorption measurements were subsequently adjusted from the weighting of excitation by the LEDs to that by the in situ light field, $\sigma_{\text {PSII }}^{\prime}$,in situ $\left(\AA^{2}\right.$ quanta $\left.^{-1}\right)$, as

$\sigma_{\mathrm{PSII}^{\prime}, \text { in situ }}=\left(\frac{\sigma_{\mathrm{PSII}^{\prime}, 478}}{\bar{a}(F R R)} \bar{a}(\right.$ in situ $\left.)\right)$.

Particulate absorption measurements were only taken during AMT 11. Therefore, we established a relationship between the ratio of $\bar{a}$ (FRR) to $\bar{a}$ (in situ) and optical depth that also was applied to the AMT 6-10 data (Fig. 2). As expected, $\bar{a}$ (FRR): $\bar{a}$ (in situ) decreased exponentially with optical depth. The LEDs of the FRR fluorometer are blue (peak $\lambda$ of $478 \mathrm{~nm}$ ) and the convergence between $\bar{a}$ (FRR) and $\bar{a}$ (in situ) reflected the exponential attenuation in situ of higher wavelength light with depth (not shown). We observed little variability of $\bar{a}$ (FRR): $\bar{a}$ (in situ) between provinces (ca. $\pm 15-20 \%$ ) (Fig. 2). Therefore, we used a single exponential function to describe $\bar{a}$ (FRR): $\bar{a}$ (in situ) upon optical depth to modify Eq. (6) and convert $\sigma_{\mathrm{PSII}, 478}$ to $\sigma_{\mathrm{PSII}}{ }_{\text {, in situ }}$

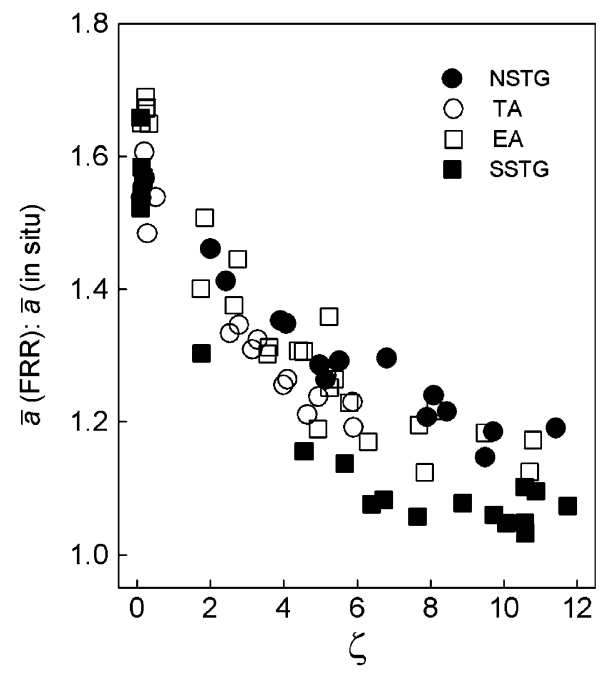

Fig. 2. Relationship between the ratio of absorption weighted by the LED excitation spectrum of the FRR fluorometer, $\bar{a}$ (FRR) $\left(\mathrm{m}^{-1}\right)$, to absorption weighted by the in situ spectrum, $\bar{a}$ (in situ) $\left(\mathrm{m}^{-1}\right)$, and the optical depth, $\zeta\left(\mathrm{m} \mathrm{m}^{-1}\right)$. Optical depth $(\zeta)$ was determined as depth $(z, \mathrm{~m})$ attenuation coefficient $\left(k, \mathrm{~m}^{-1}\right)$. The attenuation coefficient was determined from the broad-band PAR sensor (400-700 nm irradiance) integrated with the FRR fluorometer. Data were collected throughout AMT 11 only and are separated by province. A single exponential function was fitted to all data, $\bar{a}$ (FRR): $\bar{a}$ (in situ) $=1.567\left(\exp ^{-0.037 \cdot \zeta}\right)$, $r^{2}=0.808, n=116, p<0.001$, from NSTG (northern subtropical gyre), NT (northern tropical), ET (eastern tropical) and SSTG (southern subtropical gyre) Atlantic provinces. for all cruises,

$\sigma_{\mathrm{PSII}^{\prime}, \text { in situ }}(z)=\left(\frac{\sigma_{\mathrm{PSII}^{\prime}, 478}(z)}{1.567 \exp ^{-0.037 \zeta}}\right)$,

where the denominator $1.57 \cdot \exp ^{-0.037 \cdot \zeta}$ describes the relationship of $\bar{a}$ (FRR): $\bar{a}$ (in situ) with optical

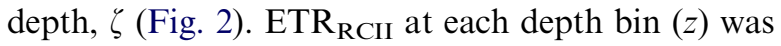
finally calculated as,

$$
\begin{aligned}
\operatorname{ETR}_{\mathrm{RCII}}(z)= & \operatorname{PPFD}(z) \sigma_{\mathrm{PSII}^{\prime}, \text { in situ }}(z) \\
& \times F_{\mathrm{q}}^{\prime} / F_{\mathrm{v}}^{\prime}(z) 0.006023 .
\end{aligned}
$$

\subsection{Fluorescence quenching parameters and $E_{k}$}

Dissipation of absorbed excitation energy can be achieved via photochemical electron turnover or alternative, non-photochemical, pathways. $F_{\mathrm{q}}{ }^{\prime} / F_{\mathrm{v}}{ }^{\prime}$ describes the trapping efficiency of PSII reaction centres (Kromkamp and Forster, 2003) and yields the proportion of absorbed excitons dissipated ('quenched') by PSII photochemistry. Effective absorption under ambient light, $\sigma_{\mathrm{PSII}}$, normalised to that in a dark acclimated state, $\sigma_{\text {PSII }}$ describes the proportion of absorbed excitons still utilisable for photochemistry on entering RCII. Thus, $1-\left(\sigma_{\mathrm{PSII}}{ }^{\prime} / \sigma_{\mathrm{PSII}}\right)$ describes the proportion of absorbed excitons dissipated as heat within the antennae bed.

A dark-adapted value of $\sigma_{\mathrm{PSII}, 478}$ was approximated for each cast using least-squares non-linear regression to fit an equation that describes the dependency of $\sigma_{\text {PSII }}{ }^{\prime} 478$ upon the PPFD (Moore et al., 2005; Smyth et al., 2004) throughout the water column,

$$
\begin{aligned}
\sigma_{\mathrm{PSII}, 478}= & {\left[\left(\sigma_{\mathrm{PSII}, 478}^{\max } E_{\mathrm{K}(\mathrm{NPQ})}\right)\right.} \\
& \left.\times\left(1-\exp \left(-\mathrm{PPFD} / E_{\mathrm{k}(\mathrm{NPQ})}\right)\right)\right] / \mathrm{PPFD} .
\end{aligned}
$$

Here, $\sigma_{\mathrm{PSII}, 478}^{\max }$ is used to differentiate a derived darkadapted effective absorption cross section from 'true' dark-adapted measurements, $\sigma_{\text {PSII,478. }}$ Eq. (9) also yields the saturating light intensity that is specific to non-photochemical quenching $\left(E_{\mathrm{k}(\mathrm{NPQ})}\right.$, $\mu$ mol photons $\left.\mathrm{m}^{-2} \mathrm{~s}^{-1}\right)$. In order to determine the light saturation parameter of photochemistry, $E_{\mathrm{k}}$ $\left(\mu \mathrm{mol}\right.$ photons $\mathrm{m}^{-2} \mathrm{~s}^{-1}$ ), we used a modified version of Eq. (9),

$$
\begin{aligned}
& \left(\frac{\sigma_{\mathrm{PSII}}, 478}{\sigma_{\mathrm{PSII}, 478}^{\max }} F_{\mathrm{q}}^{\prime} / F_{\mathrm{v}}^{\prime}\right) \\
& =\left[E_{\mathrm{K}}\left(1-\exp \left(-\mathrm{PPFD} / E_{\mathrm{k}}\right)\right)\right] / \mathrm{PPFD},
\end{aligned}
$$


where the product of $\sigma_{\mathrm{PSII}^{\prime}, 478} / \sigma_{\mathrm{PSII}, 478}^{\max }$ and $F_{\mathrm{q}}{ }^{\prime} / F_{\mathrm{v}}{ }^{\prime}$ is used to describe the PSII photochemical efficiency $(0<$ dimensionless $<1)$ (Suggett et al., 2003).

\subsection{Maximum electron turnover}

An ETR-light response describes the light-limited and light-saturated rate of electron transport (Suggett et al., 2003). This latter phenomenon is equivalent to the maximum achievable turnover rate of electrons, ETR ${ }^{\mathrm{max}}$, that is, in turn, determined by acclimative and adaptive constraints on both light harvesting and processing electrons 'downstream' of PSII (Moore et al., 2006). Least-squares non-linear regression was used to fit Eq. (11) (Jassby and Platt, 1976) to the ETR $\mathrm{RCII}$-light response throughout the water column for each cast,

$\mathrm{ETR}_{\mathrm{RCII}}=\mathrm{ETR}_{\mathrm{RCII}}^{\max }\left(1-\exp \left(-\alpha \operatorname{PPFD} / \mathrm{ETR}_{\mathrm{RCII}}^{\max }\right)\right)$,

where $\mathrm{ETR}_{\mathrm{RCII}}^{\max }$ is the maximum electron turnover (mol e $\mathrm{mol} \mathrm{RCII}^{-1} \mathrm{~s}^{-1}$ ) and $\alpha$ is the initial slope, $\left(\mathrm{mol} \mathrm{e}^{-} \mathrm{mol} \mathrm{RCII}^{-1}\right)\left(\mu \mathrm{mol} \text { photons } \mathrm{m}^{-2}\right)^{-1}$.

\section{Results}

\subsection{FRR fluorescence and fluorescence quenching}

We present parameters obtained from FRR fluorescence from AMT11 to illustrate patterns that were typically observed for all AMTs (6-11) for tropical and subtropical Atlantic provinces (Figs. 3, 4 and 6). For descriptive purposes, all measurements of dark-adapted minimum fluorescence, $F_{\mathrm{o}}, F_{\mathrm{q}}{ }^{\prime} / F_{\mathrm{v}}{ }^{\prime}$ and effective absorption were averaged into single vertical profiles within each province (Figs. 3 and 4). Peaks in $F_{\mathrm{O}}$ indicating the sub-surface chlorophyll maximum (SCM) were of higher magnitude and occurred at shallower optical depths in tropical than subtropical provinces (Fig. 3A). Both depth-specific trends and the magnitude of $F_{\mathrm{q}}{ }^{\prime} / F_{\mathrm{v}}{ }^{\prime}$ were largely similar between provinces (Fig. 3B). $F_{\mathrm{q}}{ }^{\prime} / F_{\mathrm{v}}{ }^{\prime}$ decreased, and hence photochemical quenching increased, by $57 \pm 9 \%$ (mean \pm standard error for all casts from all provinces) between the deepest and shallowest optical depths. The majority of this change occurred in the upper 4.6 optical depths, i.e shallower than

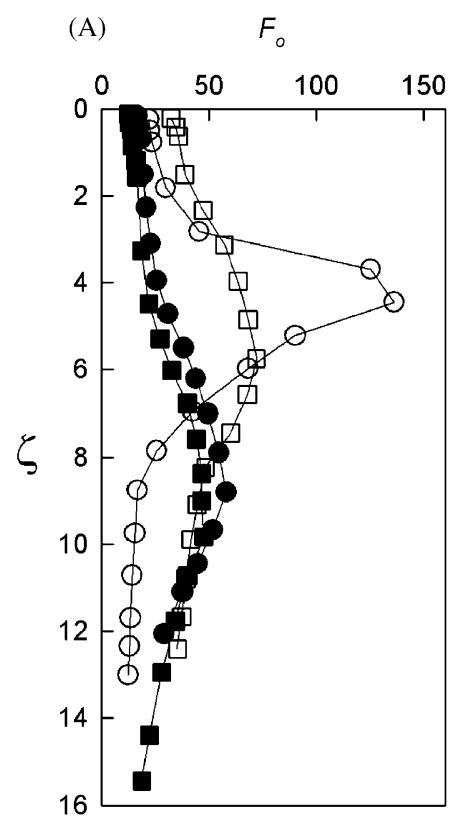

(B)

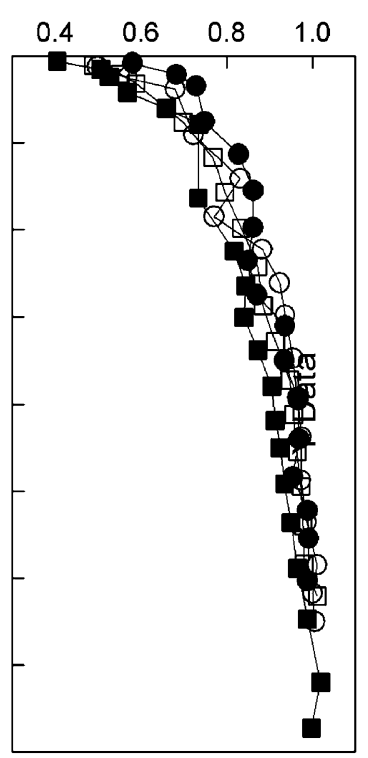

(C)

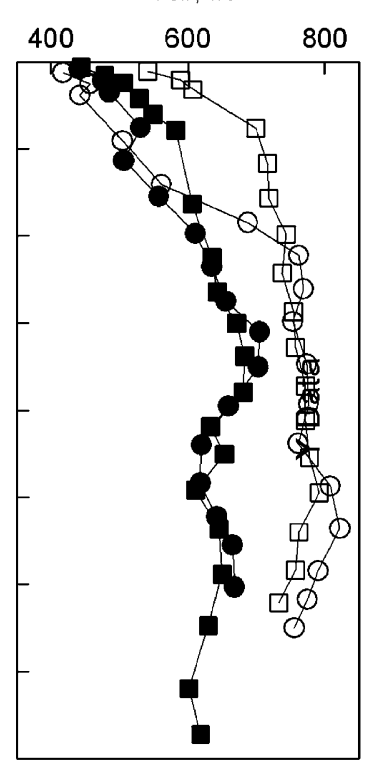

(D)

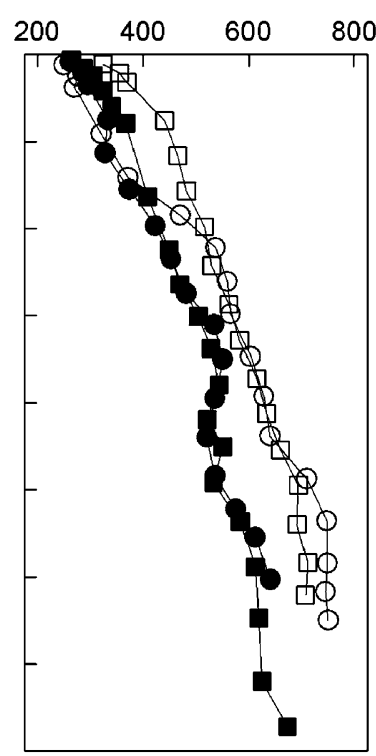

Fig. 3. Vertical profiles of (A) $F_{\mathrm{o}}$ (instrument units) (see Fig. 2), (B) PSII trapping efficiency, $F_{\mathrm{q}}{ }^{\prime} / F_{\mathrm{v}}{ }^{\prime}$ (dimensionless), (C) FRR effective absorption measured directly in situ from the FRR 'enclosed' chamber, $\sigma_{\mathrm{PSII}}{ }^{\prime}, 478\left(\AA^{2}\right.$ quanta $\left.^{-1}\right)$ and adjusted from FRR to in situ spectral quality, $\sigma_{\mathrm{PSII} \text {,in situ' }}^{\text {abs }}\left(\AA^{2}\right.$ quanta $\left.^{-1}\right)\left(\right.$ Eq. (7). $F_{\mathrm{o}}$ was derived from vertical profiles of chla concentrations interpolated to the FRR depth bins and from the relationship between $F_{\min }$ and chl $a$ at depths where quenching was negligible ( $<1 \%$ surface PPFD, not shown). Presented are the mean of all FRR depth bins from all casts within each province ( $n=4,3,7$ and 7 casts for NSTG, NT, ET and SSTG, respectively)

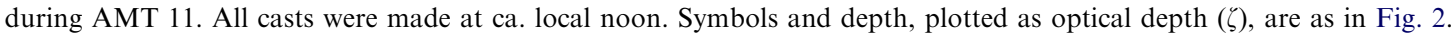



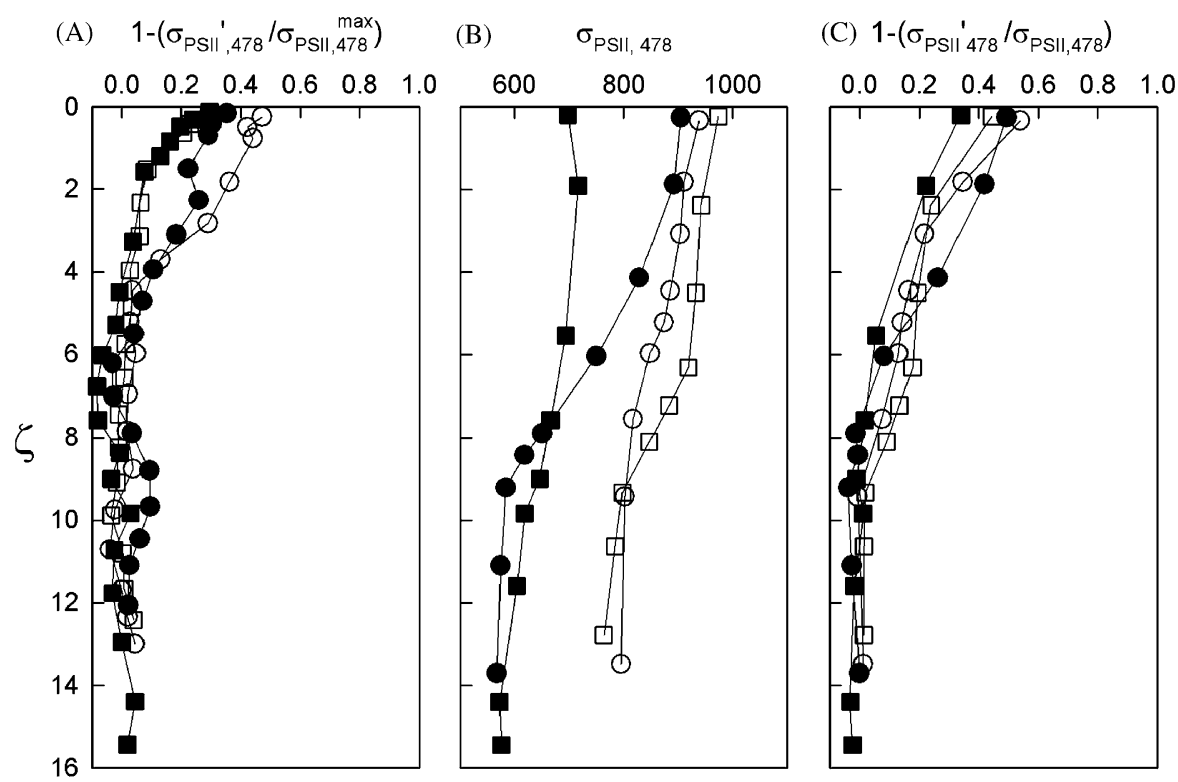

Fig. 4. Vertical profiles of (A) non-photochemical quenching, $1-\left(\sigma_{\mathrm{PSII}, 478} / \sigma_{\mathrm{PSII}, 478}^{\max }\right)$ (dimensionless), (B) Dark-adapted FRR effective absorption measured in the FRR 'enclosed' chamber in the laboratory, $\sigma_{\mathrm{PSII}, 478}\left(\mathrm{~A}^{2}\right.$ quanta $\left.^{-1}\right)$ and $(\mathrm{C})$ non-photochemical quenching, $1-\left(\sigma_{\mathrm{PSII}}^{\prime}, 478 / \sigma_{\mathrm{PSII}, 478}\right)$ (dimensionless). Data for (A) are as in Fig. 3. Data for (B) were taken from water collected during pre-dawn CTDs and binned into depths corresponding with those from the subsequent local noon in situ FRR profile during AMT 11 (see main text). Depth is plotted as in Fig. 3 and symbols are as in Fig. 2.

the $1 \%$ light depth. Depth bin-specific differences in $F_{\mathrm{q}}{ }^{\prime} / F_{\mathrm{v}}{ }^{\prime}$ between provinces were relatively small (ca. $\pm 5-15 \%$ ) except at the shallowest optical depth, ca. $\pm 20-50 \%$ (Fig. 3B).

Effective absorption cross-sections, $\sigma_{\mathrm{PSII}}{ }_{4478}$, were higher in tropical than subtropical provinces (Fig. 3C). $\sigma_{\text {PSII }}, 478$, remained relatively constant throughout much of the water column, only declining in the uppermost two (ET, NSTG, SSTG) or four (NT) optical depths. For the northern tropical Atlantic, the optical depth at which $\sigma_{\mathrm{PSII}}{ }^{\prime} 478$, began to decrease corresponded with the depth of the $F_{\mathrm{o}}$ peak. $\sigma_{\mathrm{PSII}}{ }^{\prime}$ declined by $35 \pm 9 \%$ (mean \pm standard error for all casts from all provinces) between deepest and shallowest optical depths. Similarly, $\sigma_{\mathrm{PSII}}^{\prime}$, in situ, was also higher in tropical than subtropical provinces. However, compared to $\sigma_{\mathrm{PSII}}{ }_{4,47}, \sigma_{\mathrm{PSII}}{ }^{\prime}$,in situ decreased by a greater magnitude $(60 \pm 7 \%)$ between the deepest and shallowest optical depths (Fig. 3D).

Non-photochemical quenching in the antenna bed was approximated as $1-\left(\sigma_{\mathrm{PSII}^{\prime}, 478} / \sigma_{\mathrm{PSII}, 478}^{\max }\right)$ and increased by $38 \pm 6 \%$ between the deepest and shallowest optical depths (Fig. 4A). However, these approximations of non-photochemical quenching assume that the dark-adapted effective absorption cross-section remains constant throughout the water column. Recent evidence from both the laboratory (Suggett et al., 2004) and field (Moore et al., 2005, 2006) has demonstrated that $\sigma_{\text {PSII,478 }}$ can be highly variable both between taxa and with photoacclimatory state. This would imply that the dark-adapted effective absorption cross-section is not constant with depth where distinct phytoplankton populations occur at different depths within the water column, as frequently occurs within tropical and subtropical Atlantic provinces (Zubkov et al., 2000; Barlow et al., 2002).

We compared $\sigma_{\mathrm{PSII}, 478}^{\max }$ estimated from local noon casts with $\sigma_{\text {PSII,478 }}$ measured from the pre-dawn casts for AMT 11. This comparison required that the same body of water be measured between predawn and local noon. However, the ship had typically moved by ca. $125 \mathrm{~km}$. Temperature profiles from the two casts were considered unchanged if both absolute surface temperature and mixed layer depth did not differ by greater than $\pm 5 \%$. For any pre-dawn and local noon casts that met this criterion, $\sigma_{\mathrm{PSII}, 478}^{\max }$ estimated from the local noon casts were the same as $\sigma_{\mathrm{PSII}, 478}$ at the deepest optical depths ( $t$-test, not shown; Figs. 3 and 4). $\sigma_{\text {PSII,478 }}$ increased towards the surface and appeared relatively constant in and above the SCM (Fig. 4B). This increase of $\sigma_{\text {PSII,478 }}$ between deepest and 
shallowest optical depths was of greater magnitude in the northern Atlantic subtropical gyre (37\%) than in all other provinces $(21 \pm 4 \%)$. Values of $\sigma_{\mathrm{PSII}, 478}$ were binned into the same depths as those of $\sigma_{\mathrm{PSII}}, 478$ to enable recalculation of non-photochemical quenching as $1-\left(\sigma_{\mathrm{PSII}}{ }^{\prime}, 478 / \sigma_{\mathrm{PSII}, 478}\right)$. Using this latter approach, non-photochemical quenching increased by $52 \pm 8 \%$ between the shallowest and deepest optical depths (Fig. 4C), a value similar to that observed for photochemical quenching, $F_{\mathrm{q}}{ }^{\prime} / F_{\mathrm{v}}{ }^{\prime}$.

\subsection{Effective absorption and electron turnover}

Variability of $\sigma_{\mathrm{PSII}}$ is the direct result of alterations to the composition and intracellular arrangement of pigments in relation to PSII reaction centre content (Suggett et al., 2004; Moore et al., 2005). Therefore, we compared $\sigma_{\mathrm{PSII}, 478}$ with pigment absorption and pigment packaging but not with PSII reaction centre content since the latter was not measured. In vivo absorption was determined from specific absorption coefficients and concentrations of PS and PP pigments following Bidigare et al. (1990). All specific absorption coefficients were also weighted to correspond with the excitation spectrum of the FRR fluorometer LEDs used to measure $\sigma_{\mathrm{PSII}, 478}$ (see Suggett et al., 2004; Moore et al., 2005), $\bar{a}_{\mathrm{PS}, 478}^{*}$ and $\bar{a}_{\mathrm{PP}, 478}^{*}\left(\mathrm{~m}^{-1}\right)$. Pigment packaging was determined as FRR-weighted in vivo absorption by all pigments normalised to FRRweighted particulate absorption (see Eq. (5), $\left(\bar{a}_{\mathrm{PS}, 478}^{*}+\bar{a}_{P P, 478}^{*}\right) / \bar{a}_{, 478}$ (dimensionless).

$\sigma_{\mathrm{PSII}, 478}$ was significantly negatively correlated with the ratio of in vivo absorption by PS to PP, $\bar{a}_{\mathrm{PS}, 478}^{*}: \bar{a}_{\mathrm{PP}, 478}^{*}$ (Fig. 5A). Approximately $33 \%$ of the variability of $\sigma_{\mathrm{PSII}}$ within and between provinces was explained by $\bar{a}_{\mathrm{PS}, 478}^{*}: \bar{a}_{\mathrm{PP}, 478}^{*}$ (Fig. 5 legend). Higher values of $\sigma_{\text {PSII }}$ also corresponded with lower values of packaging, $\left(\bar{a}_{\mathrm{PS}, 478}^{*}+\bar{a}_{\mathrm{PP}, 478}^{*}\right) / \bar{a}_{, 478}$; however, this relationship was not statistically significant (Fig. 5B). These comparisons were made separately for each province but were not observed to be statistically different (Fig. 5 legend).

Calculation of the electron transport rate, $\operatorname{ETR}_{\text {RCII }}$ (Eq. 8) accounts for absolute differences in light absorption and quenching, as well as light

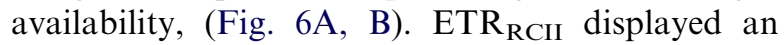
asymptotic relationship with PPFD. High lightinduced inhibition of ETR $_{\text {RCII }}$ was not observed for any of the AMT 11 casts (Fig. 6A, B) and for the majority of casts from all other AMTs (data not shown). In general, highest and lowest values of

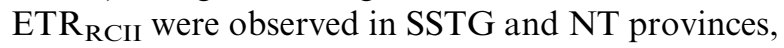

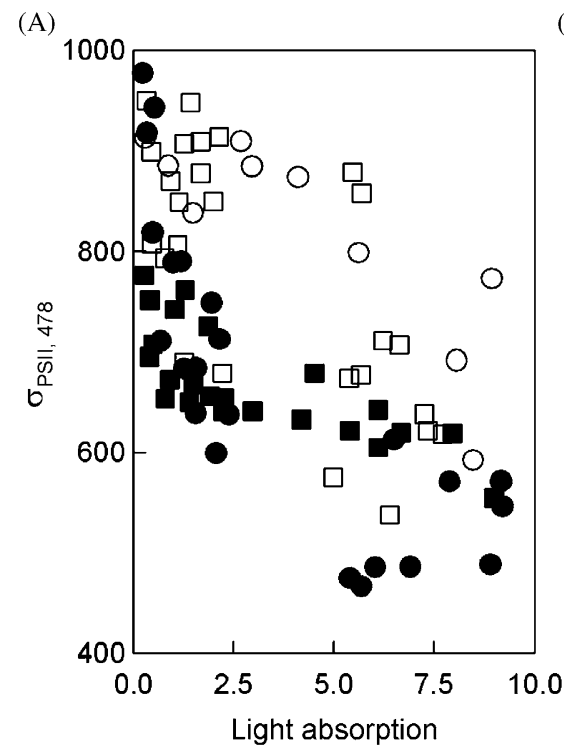

(B)

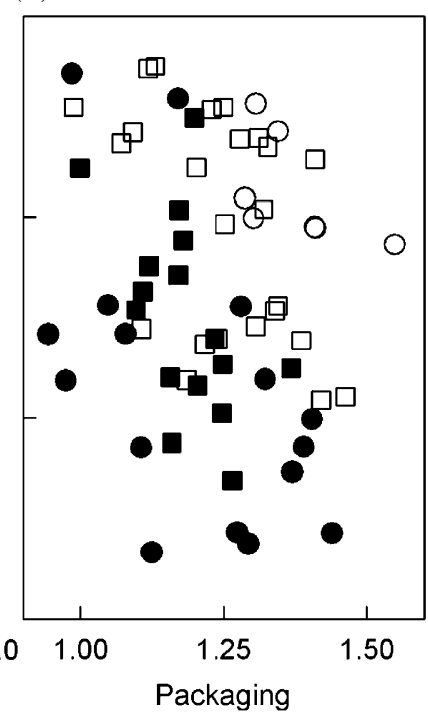

Fig. 5. Comparisons of dark-adapted effective absorption, $\sigma_{\mathrm{PSII}, 478}\left(\AA^{2}\right.$ quanta $\left.^{-1}\right)$, with (A) the ratio of in vivo absorption by 'photosynthetic' to 'photoprotective' pigments, $\bar{a}_{\mathrm{PS}, 478}^{*}: \bar{a}_{\mathrm{PP}, 478}^{*}$ (dimensionless) and (B) pigment packaging, $\left(\bar{a}_{\mathrm{PS}, 478}^{*}+\bar{a}_{\mathrm{PP}, 478}^{*}\right) / \bar{a}_{, 478}$ (dimensionless). Regression equations for all data are $\sigma_{\mathrm{PSII}, 478}=-26.9 \cdot \bar{a}_{\mathrm{PS}, 478}^{*}: \bar{a}_{\mathrm{PP}, 478}^{*}+812, r^{2}$ (adjusted) $=0.35, n=79, p<0.001$; $s_{\mathrm{PSII}, 478}=-176.5\left(\bar{a}_{\mathrm{PS}, 478}^{*}+\bar{a}_{\mathrm{PP}, 478}^{*}\right) / \bar{a}_{478}+947, r^{2}$ (adjusted) $=0.02, n=62, p=0.15$. ANCOVA analyses were performed on $\sigma_{\mathrm{PSII}, 478}$ using either absorption or packaging as the covariate to determine for differences in the regression between provinces. However, no significant differences were observed in either analysis. Symbols are as in Fig. 2. 

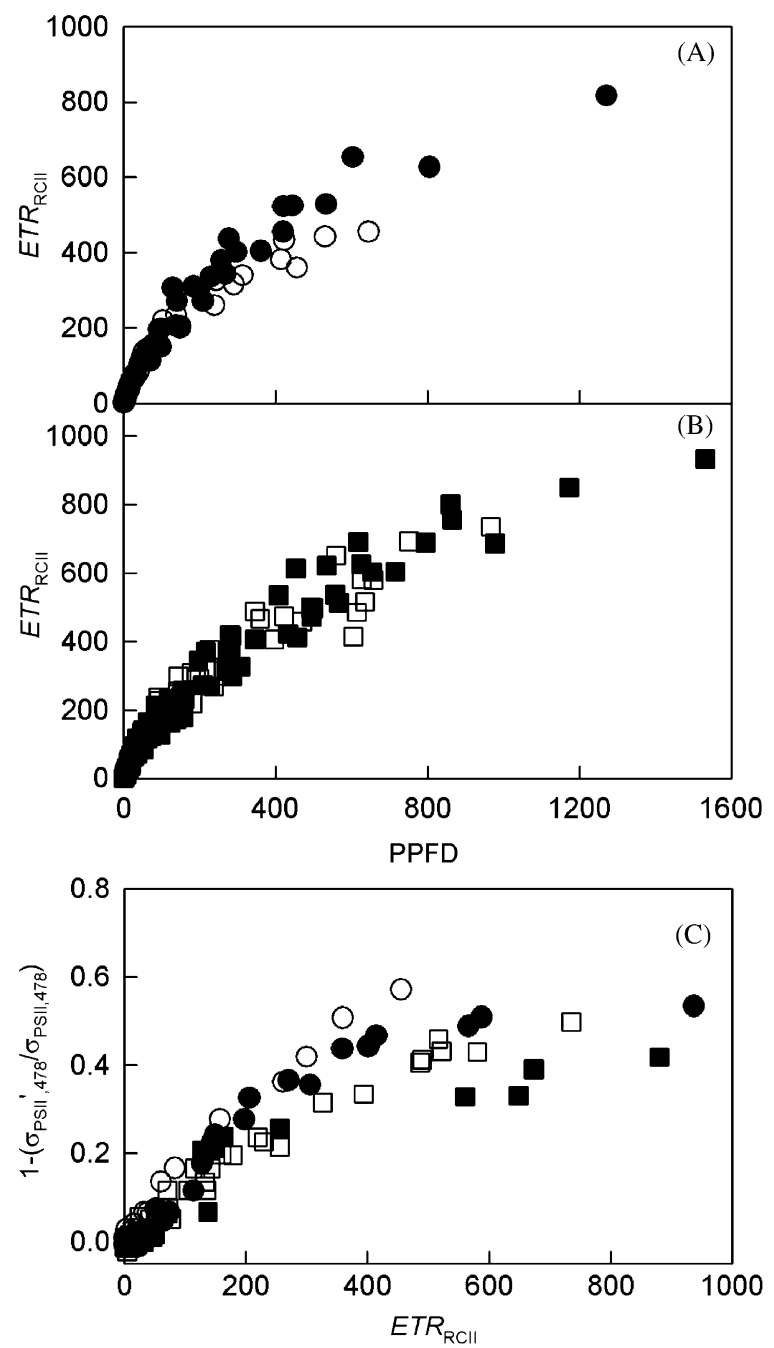

Fig. 6. (A and B) RCII-normalised electron transport rates, ETR $_{\text {RCII }}\left(\mathrm{mol} \mathrm{e}^{-}\right.$mol RCII s$\left.^{-1}\right)$ determined in situ and (C) nonphotochemical quenching, $1-\left(\sigma_{\mathrm{PSII}}{ }^{\prime} 478 / \sigma_{\mathrm{PSII}, 478}\right)$ (dimensionless) versus photosynthetically active photon flux density, PPFD $\left(\mu \mathrm{mol} \mathrm{m}{ }^{-2} \mathrm{~s}^{-1}\right)$ for AMT 11. From fits of Eq. (11) to plots of ETR $_{\mathrm{RCII}}$ versus PPFD $\left(r^{2}=0.97-0.99\right)$, Mean \pm standard error of $\mathrm{ETR}_{\mathrm{RCII}}^{\max }$ and $\alpha$ were $689 \pm 45$ and $2.08 \pm 0.15,445 \pm 8$ and $2.26 \pm 0.16,622 \pm 39$ and $2.43 \pm 0.21,820 \pm 44$, and $1.74 \pm 0.24$ for

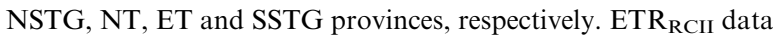
shown are for all casts and from all FRR depth bins within each province. Number of casts per province and symbols are as in Figs. 3 and 2, respectively.

respectively. These $\mathrm{ETR}_{\mathrm{RCII}}$-light response relationships inherently describe operation of non-photochemical quenching within the antenna bed. ETR $_{\text {RCII }}$ for any given PPFD reflected increasing estimates of antenna bed non-photochemical quenching, 1- $\left(\sigma_{\mathrm{PSII}}{ }^{\prime}, 478 / \sigma_{\mathrm{PSII}, 478}\right)$, between SSTG, ET, NSTG and ultimately NT provinces (Fig. 6C).

\subsection{Latitudinal variability of light absorption and maximum electron turnover}

$\sigma_{\mathrm{PSII}, 478}^{\max }$ and $E_{\mathrm{k}}$ were determined using Eqs. (9) and (10), respectively. As with the water-column profiles (Fig. 4), highest $\sigma_{\text {PSII,478 }}^{\max }$ values throughout AMT11 were observed in tropical provinces (Fig. 7A). This same pattern was also evident for $\sigma_{\text {PSII,478 }}^{\max }$ calculated from all other AMTs (Fig. 7B, Table 2). Within province differences in absolute values of $\sigma_{\mathrm{PSII}, 478}^{\max }$ from all cruises were as much as ca. $150 \AA^{2}$ quanta $^{-1}$, in particular in NSTG and tropical provinces. However, overall the $\sigma_{\mathrm{PSII}, 478}^{\max }$ values from the tropics were significantly higher than those from the subtropical gyres (Table 2).

The light saturation parameter, $E_{\mathrm{k}}$, was higher throughout the subtropical gyres and ET than throughout the NT during AMT 11 (Fig. 7C). $E_{\mathrm{k}}$ did not strictly follow this pattern between provinces from the other AMTs but remained relatively high in the NT during AMT7 and low in the NSTG during AMTs 8 and 10 (Fig. 7D). $E_{\mathrm{k}}$ considered from all cruises was significantly higher in south Atlantic (SSTG, ET and WT) than in north Atlantic (NSTG and NT) provinces (Table 2).

ETR $_{\mathrm{RCII}}^{\max }$ was determined from the light response of $\operatorname{ETR}_{\mathrm{RCII}}$ (Eq. 11). ETR $\mathrm{RCII}^{\max }$ co-varied with $E_{\mathrm{k}}$ for the complete data set, $(r=0.589, p<0.001$, not shown). Highest and lowest values of $\mathrm{ETR}_{\mathrm{RCII}}^{\max }$ during AMT 11 were observed throughout the SSTG and NT, respectively (Fig. 7E, see also Fig. 6). However, variability of ETR $\mathrm{RCII}_{\mathrm{max}}$ between provinces was different for other AMTs (Fig. 7F). ETR $\mathrm{RCII}_{\mathrm{m}}$ remained high in the WT during AMT9 and in the NT during AMT7 and low in the NSTG during AMTs 7-9. As with $E_{\mathrm{k}}$, values of $\mathrm{ETR}_{\mathrm{RCII}}^{\mathrm{max}}$ considered from all cruises were significantly higher in the southern Atlantic than in the northern Atlantic provinces (Table 2). These systematic patterns of $E_{\mathrm{k}}$ and $\mathrm{ETR}_{\mathrm{RCII}}^{\max }$ may partly reflect the nature of the AMT 6-11 cruise tracks. Specifically, in contrast to the southern subtropical gyre, samples from the northern subtropical gyre were collected within a region influenced by the northern and equatorial upwelling and not within the core of the gyre (Fig. 1). Seasonal variability between AMT cruises may have contributed to such potential patterns of variability. However, values of $\sigma_{\mathrm{PSII}, 478}^{\mathrm{max}}, E_{\mathrm{k}}$ and ETR $\mathrm{RCII}_{\mathrm{RCI}}$ from AMTs 6, 8 and 10, Austral autumn and Boreal spring, were not observed to be statistically different from those from AMTs 7, 9 and 11, Austral autumn and Boreal spring (data not shown). 

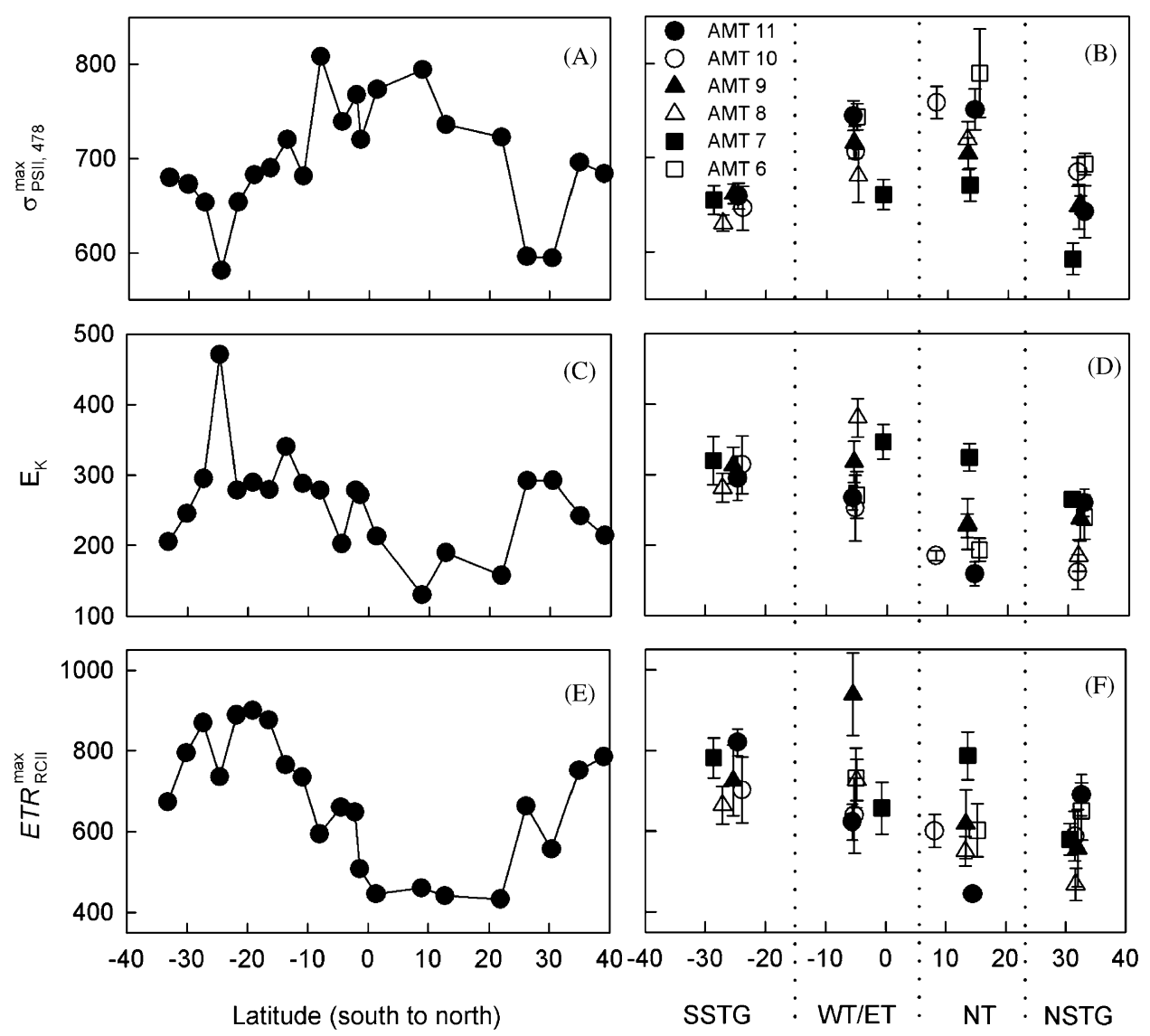

Fig. 7. (A and B) Approximated dark-adapted FRR effective absorption, $\sigma_{\mathrm{PSII}, 478}^{\max },\left(\AA^{2}\right.$ quanta $\left.^{-1}\right),(\mathrm{C}$ and D) light saturation parameter, $E_{\mathrm{k}}\left(\mu \mathrm{mol}\right.$ photons $\left.\mathrm{m}^{-2} \mathrm{~s}^{-1}\right)$, and $(\mathrm{E}$ and $\mathrm{F}) \mathrm{RCII}$-normalised maximum electron turnover, $\mathrm{ETR}_{\mathrm{RCII}}^{\max }\left(\mathrm{mol} \mathrm{e}^{-} \mathrm{mol} \mathrm{RCII} \mathrm{s}^{-1}\right)$, for the tropical and subtropical provinces. Panels A, C and E show all casts made during AMT 11. Panels B, D and F show the mean \pm standard error for all casts within each province during AMTs 6-11 (note that the error bars for latitude are not shown).

Table 2

Mean \pm standard error mixed layer depth (MLD, m), sea surface temperature $\left(\mathrm{SST},{ }^{\circ} \mathrm{C}\right)$, daily integrated PPFD (mol photons ${ }^{-2}$ ),

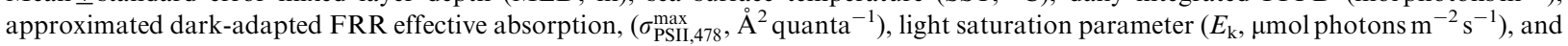
maximum electron turnover per unit PSII reaction centre $\left(\mathrm{ETR}_{\mathrm{RCII}}^{\max }\right.$, mol $\left.\mathrm{e}^{-} \mathrm{mol} \mathrm{RCII} \mathrm{s}^{-1}\right)$ from AMTs 6-11 for each tropical and subtropical province

\begin{tabular}{|c|c|c|c|c|c|c|c|}
\hline Province & $n$ & MLD & SST & Integrated daily PPFD & $\sigma_{\mathrm{PSII}, 478}^{\max }$ & $E_{\mathrm{k}}$ & $\mathrm{ETR}_{\mathrm{RCII}}^{\max }$ \\
\hline NSTG & 23 & $96.9(7.7)^{\mathrm{a}}$ & $21.6(0.6)^{\mathrm{a}}$ & $39.0(1.2)^{\mathrm{a}}$ & $645.5(9.2)^{\mathrm{a}}$ & $225.4(12.0)^{\mathrm{a}}$ & $582.4(22.0)^{\mathrm{a}}$ \\
\hline NT & 20 & $35.7(2.9)^{\mathrm{b}}$ & $26.3(0.6)^{\mathrm{b}}$ & $34.9(1.3)^{\mathrm{b}}$ & $725.7(12.9)^{\mathrm{b}}$ & $227.8(15.8)^{\mathrm{a}}$ & $608.0(28.8)^{\mathrm{a}}$ \\
\hline ET & 18 & $67.9(7.5)^{\mathrm{c}}$ & $25.5(0.5)^{\mathrm{b}}$ & $32.7(1.6)^{\mathrm{c}}$ & $729.5(10.2)^{\mathrm{b}}$ & $294.1(18.3)^{\mathrm{b}}$ & $687.2(35.6)^{\mathrm{b}}$ \\
\hline WT & 11 & $98.1(11.8)^{\mathrm{a}}$ & $27.2(0.4)^{\mathrm{b}}$ & $34.7(2.4)^{\mathrm{b}}$ & $687.0(11.2)^{\mathrm{c}}$ & $307.3(20.8)^{\mathrm{b}}$ & $717.6(66.4)^{b}$ \\
\hline SSTG & 23 & $139.6(7.2)^{\mathrm{d}}$ & $22.5(0.6)^{\mathrm{a}}$ & $38.1(2.2)^{\mathrm{a}}$ & $649.7(6.12)^{\mathrm{a}}$ & $300.9(16.3)^{\mathrm{b}}$ & $736.4(27.6)^{b}$ \\
\hline$A N O V A \mathrm{~F}$ & & 27.99 & 38.61 & 3.68 & 16.62 & 10.84 & 9.64 \\
\hline
\end{tabular}

ANOVA $\left(F_{\text {critical }}=2.306\right.$, all $p<0.001$, except daily integrated PPFD, $\left.p=0.028\right)$ and Tukey-test with unequal variance $(q$ critical $=4.431)$. Superscript letters indicate significantly different data groupings from Tukey test.

\subsection{Environmental regulation of electron turnover}

In order to explain the observed variability of $\sigma_{\mathrm{PSII}, 478}^{\max }, E_{\mathrm{k}}$ and $\mathrm{ETR}^{\max }$ within and between pro- vinces across AMT cruises, we considered the temperature and light environment. Mixed-layer depth (MLD) and sea-surface temperature (SST) were determined from CTD profiles that corresponded 
with the FRR fluorescence profiles. As expected, SSTs were lower in subtropical than in tropical provinces (Table 2). MLD was determined as the shallowest depth at which the change in temperature with depth exceeded $0.1{ }^{\circ} \mathrm{Cm}^{-1}$ (Hooker et al., 2000). Shallowest and deepest MLDs were observed in the NT and SSTG, respectively (Table 2). Highest and lowest daily integrated PPFDs were observed in the subtropical gyres and ET, respectively (Table 2).

Values of $\sigma_{\mathrm{PSII}, 478}^{\max }$ were strongly negatively correlated with, and largely explained by changes in, both MLD (Fig. 8A) and integrated daily PPFD (Fig. 8D) when considering data from all cruises (Table 3). A similar pattern was not observed when these data from each province were compared separately (Table 3). Variability of $\sigma_{\text {PSII,478 }}^{\max }$ was partly explained by changes in SST for the tropical provinces (Table 3).

Patterns of variability for $E_{\mathrm{k}}$ and $\mathrm{ETR}_{\mathrm{RCII}}^{\max }$ contrasted with those observed for $\sigma_{\mathrm{PSII}, 478 \text {. Both }}^{\max }$ $E_{\mathrm{k}}$ and $\mathrm{ETR}_{\mathrm{RCII}}^{\max }$ were highly positively correlated with MLD (Figs. 8B and C) and integrated daily PPFD (Figs. 8E and F) when considering data from all cruises (Table 3). Furthermore, in contrast to $\sigma_{\mathrm{PSII}, 478}^{\max }$, correlations of $E_{\mathrm{k}}$ and $\mathrm{ETR}_{\mathrm{RCII}}^{\max }$ with MLD and daily integrated PPFD were largely preserved when treating these data for each province separately (Table 3 ). $E_{\mathrm{k}}$ and $\mathrm{ETR}_{\mathrm{RCII}}^{\max }$ were not explained by changes in SST.
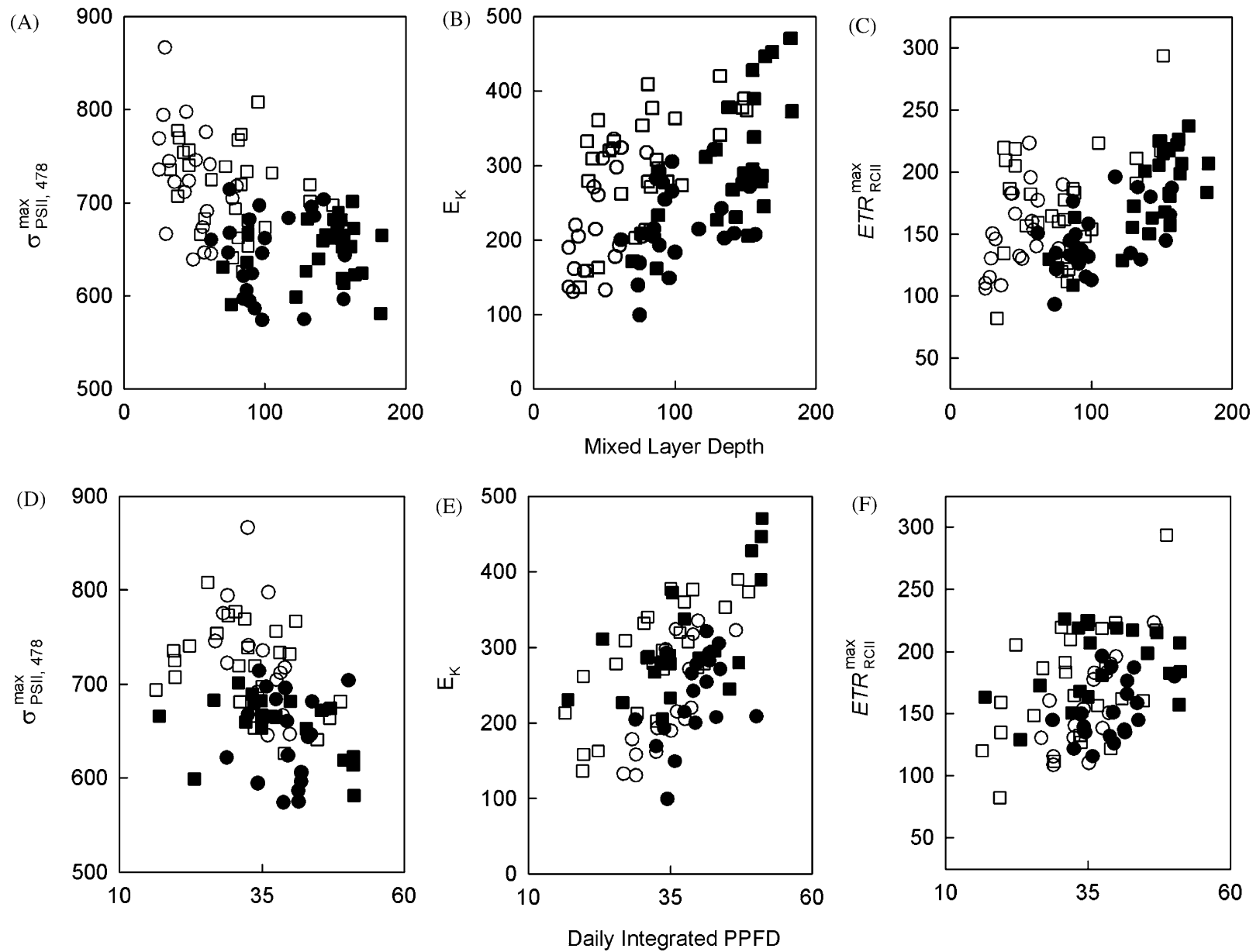

Fig. 8. Comparisons of $\sigma_{\text {PSII,478 }}^{\max }\left(\AA^{2}\right.$ quanta $\left.^{-1}\right), E_{\mathrm{k}}\left(\mu \mathrm{mol}\right.$ photons $\left.\mathrm{m}^{-2} \mathrm{~s}^{-1}\right)$ and $\mathrm{ETR}_{\mathrm{RCII}}^{\max }\left(\mathrm{mol}^{-}\right.$mol RCII s$\left.{ }^{-1}\right)$ against $(\mathrm{A}-\mathrm{C})$ mixed layer depth (MLD, $\mathrm{m}$ ) and (D-F) daily integrated PPFD (mol photons $\mathrm{m}^{-2}$ ). Determinations of MLD and daily integrated PPFD are given in the main text. All data from throughout AMTs 6-11 are shown for each province. Symbols for provinces are as in Fig. 2, except where WT replaces ET for AMTs 7, 9 and 10 (Table 1). Correlation coefficients are given in Table 3. 
Table 3

Summary of forward stepwise regressions performed between the dependent variables approximated dark-adapted FRR effective absorption, $\left(\sigma_{\mathrm{PSII}, 478}^{\max }, \AA^{2}\right.$ quanta $\left.{ }^{-1}\right)$, light saturation parameter $\left(E_{\mathrm{k}}, \mu \mathrm{mol}\right.$ photons $\left.\mathrm{m}^{-2} \mathrm{~s}^{-1}\right)$ or maximum electron turnover $\left(\mathrm{ETR}_{\mathrm{RCII}}^{\max }\right.$, mol $\mathrm{e}^{-} \mathrm{mol} \mathrm{RCII} \mathrm{s}^{-1}$ ) and independent variables of mixed layer depth (MLD, m), daily integrated PPFD (mol photons $\mathrm{m}^{-2}$ ) and sea surface temperature $\left(\mathrm{SST},{ }^{\circ} \mathrm{C}\right)$

\begin{tabular}{|c|c|c|c|c|c|c|c|c|}
\hline \multirow[t]{2}{*}{ Province } & \multirow[t]{2}{*}{ Dependent variable } & \multicolumn{2}{|l|}{ MLD } & \multicolumn{2}{|c|}{ Integrated daily PPFD } & \multicolumn{2}{|l|}{ SST } & \multirow[b]{2}{*}{$r^{2}$} \\
\hline & & $\%$ var & $(P)$ & $\%$ var & $(P)$ & $\%$ var & $(P)$ & \\
\hline All & \multirow[t]{5}{*}{$\sigma_{\mathrm{PSII}, 478}^{\max }$} & 17 & $(* *)$ & 14 & $(* *)$ & 11 & $(*)$ & 0.388 \\
\hline NSTG & & 4 & (NS) & $<1$ & (NS) & 13 & (NS) & 0.164 \\
\hline NT & & 13 & (NS) & 19 & $(*)$ & 17 & $(*)$ & 0.489 \\
\hline $\mathrm{ET} / \mathrm{WT}$ & & 8 & (NS) & 10 & (NS) & 15 & $(*)$ & 0.331 \\
\hline SSTG & & 3 & (NS) & 11 & $(\mathrm{NS})$ & 8 & (NS) & 0.238 \\
\hline All & \multirow[t]{5}{*}{$E_{\mathrm{k}}$} & 20 & $(* *)$ & 21 & $(* *)$ & 3 & (NS) & 0.438 \\
\hline NSTG & & 10 & (NS) & 14 & $(*)$ & 19 & $(*)$ & 0.431 \\
\hline NT & & 19 & $(*)$ & 44 & $(* *)$ & 7 & $(\mathrm{NS})$ & 0.709 \\
\hline $\mathrm{ET} / \mathrm{WT}$ & & 21 & $(*)$ & 41 & $(* *)$ & $<1$ & (NS) & 0.626 \\
\hline SSTG & & 31 & $(* *)$ & 33 & $(* *)$ & 4 & (NS) & 0.683 \\
\hline All & \multirow[t]{5}{*}{$\mathrm{ETR}_{\mathrm{RCII}}^{\max }$} & 17 & $(* *)$ & 12 & $(* *)$ & 1 & (NS) & 0.301 \\
\hline NSTG & & 19 & $(*)$ & 16 & $(*)$ & 5 & (NS) & 0.390 \\
\hline NT & & 22 & $(*)$ & 43 & $(* *)$ & 3 & (NS) & 0.682 \\
\hline $\mathrm{ET} / \mathrm{WT}$ & & 14 & $(*)$ & 18 & $(*)$ & $<1$ & (NS) & 0.328 \\
\hline SSTG & & 41 & $(* *)$ & 12 & $(*)$ & 4 & (NS) & 0.573 \\
\hline
\end{tabular}

Shown is the \% variance (and $P$, significance levels) explained by each independent variable. Significance levels are $* 0.05>p>0.001$, $* * p<0.001$ or NS (not significant), $p>0.05$.

\section{Discussion}

\subsection{Variability of PSII light absorption}

Dark-adapted measurements of the effective absorption cross section, $\sigma_{\mathrm{PSII}}$, are affected by both physiological (phenotypic) and taxonomic (genotypic) signatures of the phytoplankton community (Suggett et al., 2004; Moore et al. 2005, 2006). Specifically, smaller $\sigma_{\mathrm{PSII}}$ values are indicative of large eukaryotes or cyanobacteria but may also indicate a down-regulation in light harvesting for photochemistry; higher $\sigma_{\mathrm{PSII}}$ values are indicative of smaller eukaryotes but also an up-regulation of light harvesting for photochemistry (Suggett et al., 2004). Some evidence suggest that cyanobacteria Prochlorococcus spp. have higher $\sigma_{\mathrm{PSII}}$ than Synechococcus spp. (see Behrenfeld and Kolber, 1999; Steglich et al., 2001). Consequently, interpretation of $\sigma_{\text {PSII }}$ variability in nature is not trivial. Our recent laboratory (Suggett et al., 2004) and field (Moore et al., 2005, 2006) data suggests a dominance of taxonomic over physiological variability upon $\sigma_{\mathrm{PSII}}$ is likely in many systems.

Systematic changes of both taxa and microalgal pigments are observed between subtropical and tropical Atlantic provinces. Picoeukaryotes, Synechococcus and Prochlorococcus dominate biomass throughout these provinces; however, typically picoeukaryotes and Synechococcus predominate the northern tropical Atlantic and, to a lesser extent the equatorial upwelling, whilst Prochlorococcus predominates the tropical equatorial and subtropical gyres (Zubkov et al., 2000). At the same time, the ratio of PS to PP pigments is lower in tropical than subtropical gyre provinces (Barlow et al., 2002). As such, lower mean values of $\sigma_{\text {PSII }}$ within the subtropical gyres than within the tropical provinces would appear to be consistent with independent observations from taxonomy and microalgal pigments. Similar trends for $\sigma_{\mathrm{PSII}}$ throughout the subtropical and tropical Atlantic have been reported previously (Behrenfeld and Kolber, 1999, see also Babin et al., 1996).

$\sigma_{\mathrm{PSII}, 478}$ was better explained by variations in the ratio of PS:PP than by pigment packaging. Within the water column, $\sigma_{\mathrm{PSII}, 478}$ was negatively correlated with PS:PP since $\sigma_{\text {PSII }}$ increased (Fig. 4) whilst PS:PP decreased (not shown) towards the surface. We would expect $\sigma_{\mathrm{PSII}}$ to be positively correlated with the ratio of PS:PP pigment concentration, where the rate of PSII reaction centre closure is 
largely modified by the proportion of pigmentation within the antennae bed that delivers absorbed photons into PSII reaction centres (Suggett et al., 2004; Moore et al., 2005). Therefore, the negative correlation between $\sigma_{\mathrm{PSII}, 478}$ and PS:PP may signify that $\sigma_{\mathrm{PSII}, 478}$ is largely controlled by PSII reaction centre content and not pigmentation in these provinces (see Section 4.4.) or existence of shift in the taxonomic composition and hence of $\sigma_{\text {PSII,478 }}$ and PS:PP within the water column. Variations in pigment packaging can account for much of the variability of both optical (Stæhr et al., 2003. Bricaud et al., 2004) and biophysical (Moore et al. 2005, 2006) absorption measurements when large changes of nutrient status and thus phytoplankton cell size of the system in question are encountered. However, the subtropical and tropical Atlantic systems we investigated are oligotrophic and largely dominated by small cells (Zubkov et al., 2000; Marañón et al., 2003).

Each ETR calculation is the product of effective absorption cross-section and actinic PPFD to yield the rate of light absorption. As such, $\sigma_{\mathrm{PSII}}$ or $\sigma_{\mathrm{PSII}, 478}^{\max }$ is equivalent to the initial slope $(\alpha)$ of conventional light-response productivity experiments. Investigations from $\mathrm{C}$-uptake have shown that $\alpha$ is generally less variable than $P^{\max }$ throughout tropical and subtropical provinces (Sathyendranath et al., 1995; Marañón and Holligan, 1999; Teira et al., 2005). Similarly, our derived darkadapted effective absorption, $\sigma_{\mathrm{PSII}, 478}^{\max }$, showed considerably less variability both within and between provinces than $\mathrm{ETR}_{\mathrm{RCII}}^{\max }$ (Table 2).

High co-variability was observed between $\sigma_{\mathrm{PSII}, 478}^{\max }$ and MLD, integrated daily PPFD and, to a lesser extent, SST when data from all provinces was considered together. Therefore, selective pressure on taxa with differing $\sigma_{\text {PSII }}$ may have been driven in part by the broad-scale changes in the light climate. Both the daily-integrated PPFD and the degree of mixing, as inferred from the mixed layer depth (and SSTs), control the photon dose received within the euphotic zone. As such, the lack of co-variability between $\sigma_{\mathrm{PSII}, 478}^{\max }$ and environmental variables when data from each province were treated separately (Table 3) and the negative correlation of $\sigma_{\mathrm{PSII}, 478}^{\max }$ with daily-integrated PPFD at the broadest scales (Fig. 8a, Table 3) further support the suggestion that taxonomic variability between provinces most likely accounted for the greatest changes in effective absorption.

\subsection{Variability of $\mathrm{ETR}_{R C I I}^{\max }$ and $E_{k}$}

Maximum RCII-normalised electron turnover rate, $\mathrm{ETR}_{\mathrm{RCII}}^{\max }$, and saturating light intensity, $E_{\mathrm{k}}$, values also varied systematically between provinces. $\mathrm{ETR}_{\mathrm{RCII}}^{\max }$ was ca. $20 \%$ higher in the southern subtropical gyre, eastern and western tropical Atlantic than in the northern tropical Atlantic and northern subtropical gyre (Table 2). These systematic variations of $\mathrm{ETR}_{\mathrm{RCII}}^{\max }$ contrast with those of $P^{\max }$ that have been determined from carbon uptake measurements since $P^{\max }$ is typically higher in tropical Atlantic than in subtropical gyre provinces (Marañón and Holligan, 1999; Marañón et al., 2000; Marañón, 2005; Teira et al., 2005; Pérez et al., 2005). Consequently, variations of $\mathrm{ETR}_{\mathrm{RCII}}^{\mathrm{max}}$ observed here imply a broad scale decoupling of energetic potential for photosynthesis from actual carbon that is fixed. We return to this observation in Section 4.5.

\subsection{Regulation of $\mathrm{ETR}_{R C I I}^{\max }$ and PSII light absorption}

Phytoplankton communities adjust their photochemical constituents and pathways towards an acclimatory state that can be characterised by their rate of cellular light absorption, saturating light-intensity and maximum rate of cellular production (Allen, 2002; MacIntyre et al., 2002; Behrenfeld et al., 2004). This dynamic process of photoacclimation is described here by $\sigma_{\mathrm{PSII}, 478}$ and $\sigma_{\mathrm{PSII}, 478}^{\max }, E_{\mathrm{k}}$ and $\mathrm{ETR}_{\mathrm{RCII}}^{\max }$. We observed systematic coupling of all three parameters with MLD and daily-integrated PPFDs (Fig. 8, Sections 4.1 and 4.2.). As such, ETR $\mathrm{RCII}_{\mathrm{max}}$ (MacIntyre et al., 2002; Behrenfeld et al., 2004; Moore et al., 2006) and in turn community metabolism (Suggett, Maberly and Geider, unpubl.) will be determined by changes in PSII light absorption.

Systematic coupling between $\mathrm{ETR}_{\mathrm{RCII}}^{\max }, E_{\mathrm{k}}$, integrated PPFD, and MLD would be expected if $\mathrm{ETR}_{\mathrm{RCII}}^{\max }$ is to some degree regulated by PSII light absorption. However, this photoacclimation response breaks down when our data are considered in more detail. $E_{\mathrm{k}}$ and $\mathrm{ETR}_{\mathrm{RCII}}^{\max }$ but not $\sigma_{\mathrm{PSII}, 478}^{\max }$ are explained by changes in both MLD and integrated PPFD when data from each province are treated individually (Table 3). Several reasons may account for this inconsistent behaviour between $\sigma_{\mathrm{PSII}, 478}^{\max }, E_{\mathrm{k}}$ and $\mathrm{ETR}_{\mathrm{RCII}}^{\max }$.

Firstly, $\sigma_{\mathrm{PSII}}$ and $\mathrm{ETR}_{\mathrm{RCII}}^{\max }$ are dynamically regulated by different photochemical constituents. 
$\mathrm{ETR}_{\mathrm{RCII}}^{\max }$ is the maximum turnover rate of the primary photochemical acceptor quinone termed $Q_{\mathrm{A}}$. Therefore, adjustments in the pool size and/or activity of photosystem components downstream of $Q_{\mathrm{A}}$ may account for variability of $\mathrm{ETR}_{\mathrm{RCII}}^{\max }$ (Behrenfeld et al., 2004). Several potential mechanisms may operate in microalgae, (1) the electron donor pool size to PSI (Falkowski and Raven, 1997), (2) PSI photosynthetic unit size (3) the ratio of ETR to cyclic electron flow around PSI (Allen, 2002) and (4) Calvin cycle activity (Sukenik et al., 1987; Geider and MacIntyre, 2002). Unfortunately, we are unable to determine the significance of these various mechanisms from the data presented here. In contrast, $\sigma_{\mathrm{PSII}}$ is regulated by constituents that dissipate absorbed excitation energy from the antenna bed, specifically, the size and speciation of the PSII pigment pool and number of PSII reaction centres (Section 4.1.). $\sigma_{\text {PSII }}$ may also be modified by the degree of excitation energy spill-over from PSII to PSI and in turn state transitions (Falkowski and Raven, 1997). Under ambient light, modifications of $\sigma_{\text {PSII }}$, (Fig. 6C) are dependent upon the capacity with which ETR can build the transthylakoid $\mathrm{H}+$ gradient (Allen, 2002; Kramer et al., 2004; Avenson et al., 2005) and on the maximum capacity for the antenna bed to quench excitation energy via processes such as xanthophyll cycling (Kramer et al., 2004).

Secondly, if light-saturated carbon fixation is controlled by the Calvin Cycle then ETR $\mathrm{RCII}_{\mathrm{R}}$ will decrease with an increase in the ratio of RCII to Calvin Cycle activity (Sukenik et al., 1987; Behrenfeld et al., 2004). Moore et al. (2006) have recently demonstrated that such regulation of RCII concentration to Calvin Cycle activity may underpin photoacclimatory regulation of electron turnover in coastal phytoplankton.

Finally, stratification of phytoplankton communities occurs in tropical and subtropical waters and results in a continuum of physiological characteristics within the euphotic zone (Morel et al., 1996; Babin et al., 1996). Therefore, entire water-column ETR profiles will cause derivations of $E_{\mathrm{k}}$ and $\operatorname{ETR}_{\mathrm{RCII}}^{\max }$ (Eq. 11) to be weighted by the characteristics of the upper water column where ETR is highest and becomes saturating for photochemistry. Under conditions of a well-defined surface mixed layer it is expected that values of $E_{\mathrm{k}}$ would be relatively uniform throughout. However, this may not be the case within the deep but relatively quiescent euphotic zone found within the tropical and sub-tropical Atlantic. In contrast, $\sigma_{\mathrm{PSII}, 478}^{\max }$ deviates from the true $\sigma_{\mathrm{PSII}, 478}$ in the upper water column (Figs. 4 and 5) and hence the actual $\alpha$ (Eq. 11, data not shown). Absolute values of $\mathrm{ETR}_{\mathrm{RCII}}^{\max }$ contain a measure of effective absorption, $\sigma_{\text {PSII,in situ }}$, that account for changes in the actual $\sigma_{\text {PSII }}$ but are inevitably biased to the upper watercolumn photophysiology and thus not strictly comparable with independent estimates of $\sigma_{\mathrm{PSII}, 478}^{\max }$.

Recognising the caveats above, integrated surface daily irradiance was the best overall predictor of $E_{\mathrm{k}}$ (Fig. 8, Table 3). The mean irradiance within $\left(\overline{\mathrm{PPFD}}_{\text {within }}\right)$ and at the base of $\left(\overline{\mathrm{PPFD}}_{\text {base }}\right)$ the mixed layer were calculated using measured optical depths and the integrated surface irradiance. However, comparisons of $E_{\mathrm{k}}$ with both $\overline{\mathrm{PPFD}}_{\text {within }}$ and $\overline{\mathrm{PPFD}}_{\text {base }}$ yielded values of $r^{2}$ lower than that observed between $E_{\mathrm{k}}$ and integrated surface daily irradiance and, more importantly, correlations that were negative. Our data thus indicate that phytoplankton populations in the sub-tropical and tropical Atlantic are acclimated to irradiances that are determined by the maximum rather than the minimum exposure. This is consistent with the data of Vincent et al. (1984) and Moore et al. (2006), albeit within markedly different environments, but contrasts with the suggestion of Behrenfeld et al. (2002) that mixed-layer populations acclimate to the irradiance at the base of the mixed layer. Marañon and Holligan (1999) found little correspondence of near surface $E_{\mathrm{k}}$ and $P^{\max }$ with mean daily irradiance. Therefore, the contrast between our data and studies based on $P^{\max }$ may provide further evidence for de-coupling of ETR from carbon fixation.

\subsection{Variability of ETRs from knowledge of PSII reaction centre content}

RCIIs are not easily quantified in nature and hence not a useful ecological denominator. As such, normalisation of $\sigma_{\mathrm{PSII}}$ and thus ETR to the number of RCIIs represents a fundamental limitation upon the interpretation of FRR fluorescence data. Laboratory investigations have shown that the chl $a$ : RCII during steady state growth can vary by upto a factor of ca. 3 between taxa and in response to photoacclimation and nutrient limitation (see Suggett et al., 2004, and references therein).

Functional PSII reaction centre concentration ([RCII], mol RCII m ${ }^{-3}$ ) can be estimated from knowledge of the biophysical effective absorption 
coefficient $\left(\sigma_{\mathrm{PSII}, 478}, \mathrm{~m}^{2}\right.$ mol quanta $\left.{ }^{-1}\right)$, light absorp-

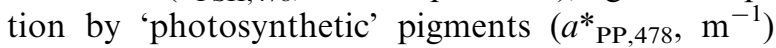
and the efficiency for transfer of absorbed light between pigments and reaction centres $\left(\psi_{t}\right.$, dimensionless) (Mauzerall and Greenbaum, 1989; Suggett et al., 2001, 2004, Moore et al., 2005, 2006),

$[\mathrm{RCII}]=\left(a_{\mathrm{PP}, 478}^{*} \psi_{\mathrm{t}}\right) / \sigma_{\mathrm{PSII}, 478}$.

$a^{*}$ PP was determined from the in vivo absorption coefficients and pigment concentrations (Bidigare et al., 1990) but must be further adjusted to account for pigment packaging ( $Q$, dimensionless), the proportion of light absorbed by PSII (PSII: PSI, dimensionless) and finally weighted to correspond with the excitation used to measure $\sigma_{\mathrm{PSII}}\left(\bar{a}_{\mathrm{PP}, 478}^{*}\right.$, following Eq. (5); but see also Suggett et al., 2004),

$[\mathrm{RCII}]=\left(\bar{a}_{\mathrm{PP}, 478}^{*} Q \mathrm{PSII}: \mathrm{PSI} \psi_{\mathrm{t}}\right) /\left(\sigma_{\mathrm{PSII}, 478} 6023\right)$.

The factor 6023 accounts for conversion of $\sigma_{\mathrm{PSII}}$ from $\AA^{2}$ quanta to $\mathrm{m}^{2} \mathrm{~mol} \mathrm{RCII}{ }^{-1}$. Similarly, the ratio of RCIIs to chlorophyll $a$, the reciprocal of the so-called 'PSII photosynthetic unit size' $\left(\mathrm{n}_{\mathrm{RCII}}\right.$, mol RCII mol chla ${ }^{-1}$ ), is determined with the additional inclusion of the chlorophyll $a$ concentration ([chla], mol chla $\mathrm{m}^{-3}$ ),

$$
\begin{aligned}
& n_{\mathrm{RCII}} \\
& \quad=\left(\bar{a}_{\mathrm{PP}, 478}^{*} Q \text { PSII }: \text { PSI } \psi_{\mathrm{t}}\right) /\left(\sigma_{\mathrm{PSII}, 478} \cdot[\mathrm{chl} a] 6023\right) .
\end{aligned}
$$

We determined both [RCII] and $n_{\mathrm{RCII}}$ from $\bar{a}_{\mathrm{PP}, 478}^{*}$ and $\sigma_{\mathrm{PSII}, 478}$ measurements made during AMT 11. $Q$ was estimated as $\left(\bar{a}_{\mathrm{PS}, 478}^{*}+\bar{a}_{\mathrm{PP}, 478}^{*}\right) / \bar{a}_{, 478}$ (Section 3.2.) whilst PSII: PSI and $\psi_{\mathrm{t}}$ were assumed to have values of 0.5 and 1.0 , respectively.

Highest and lowest estimates of [RCII] were determined for the NT and SSTG, respectively (Fig. 9A). Mean estimates of [RCII] from NSTG and ET appeared higher than those from SSTG. However, these differences were not significant. Therefore, all provinces except for NT displayed similar if highly variable estimates of PSII reaction centre concentration. In contrast, higher estimates of $n_{\mathrm{RCII}}$ were estimated for NSTG than for all other provinces (Fig. 9A). SSTG and both tropical provinces displayed a similar range of $n_{\mathrm{RCII}}$ estimates. Such variability of cellular RCII concentration may partly explain values of $\sigma_{\text {PSII }}$ that cannot be accounted for from changes in pigment content or packaging alone (Section 4.1.)

Electron transport rates per unit volume (ETR, mol $\left.\mathrm{e}^{-} \mathrm{m}^{-3} \mathrm{~s}^{-1}\right)$ or per unit chlorophyll $a\left(\right.$ ETR $_{\mathrm{chl} a}$, mol e $\mathrm{e}^{-} \mathrm{molchl} a^{-1} \mathrm{~s}^{-1}$ ) were calculated using the product of Eq. (8) and estimates of [RCII] (Eq. 13) or $n_{\mathrm{RCII}}$ (Eq. 14). For this, values of [RCII] or $n_{\mathrm{RCII}}$ were linearly interpolated throughout the water column to correspond with the FRR depth bins. Maximum ETRs per unit volume or per unit chlorophyll $a, \mathrm{ETR}^{\max }$ and $\mathrm{ETR}_{\mathrm{chl} a}^{\max }\left(\mathrm{mol} \mathrm{e}^{-} \mathrm{m}^{-3} \mathrm{~h}^{-1}\right.$ and mole $\mathrm{e}^{-} \mathrm{mgchl} a^{-1} \mathrm{~h}^{-1}$ ), respectively, were recalculated by fitting Eq. (11) to the light response of
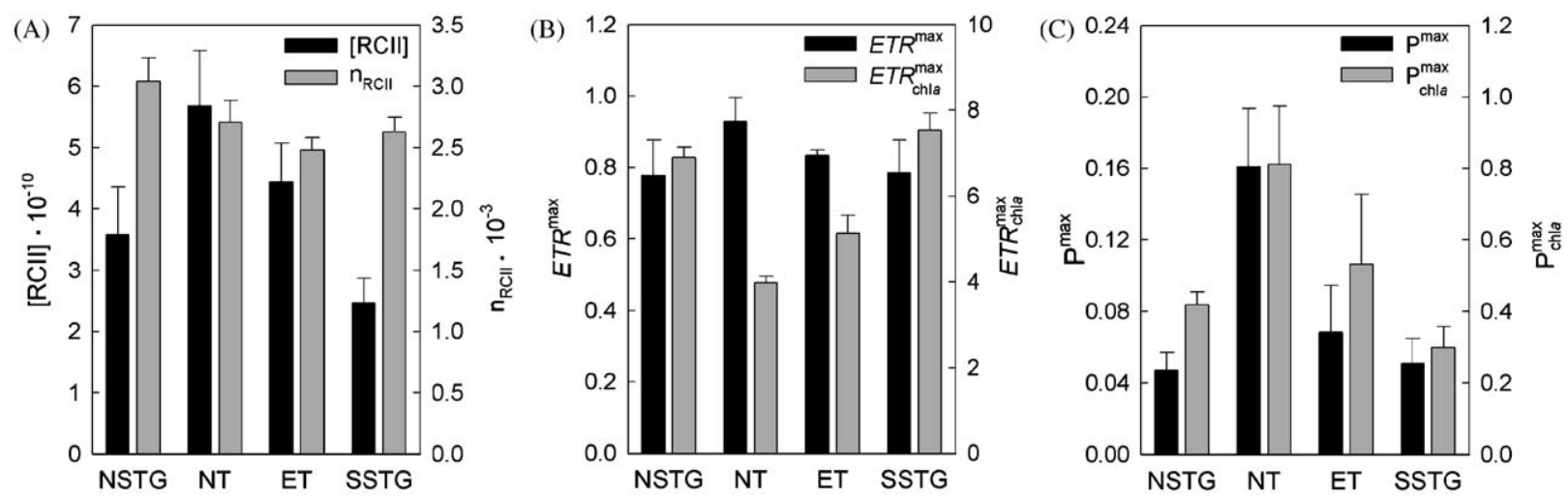

Fig. 9. Mean \pm standard error of (A) reaction centre concentration, [RCII] (Eq. 12), mol RCII m ${ }^{-3}$ ) and $n_{\mathrm{RCII}}$ (Eq. 13), mol RCII mol chl $a^{-1}$ ) and (B) maximum electron turnover rates per unit volume, ETR ${ }^{\max }\left(\mathrm{mol}^{-} \mathrm{m}^{-3} \mathrm{~h}^{-1}\right.$ ), and per unit chlorophyll $a$, $\operatorname{ETR}_{\mathrm{chl} a}^{\max }\left(\mathrm{mol} \mathrm{e}^{-} \mathrm{mg} \mathrm{chl} a \mathrm{~h}^{-1}\right)$ from data collected throughout AMT 11. These maximum electron turnover rates were determined from

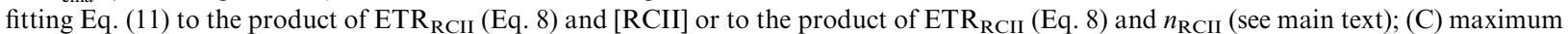

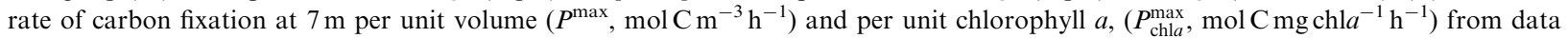
collected throughout AMTs 1-3 (see Marañón, 2005). ANOVA were performed on all data sets: $[\mathrm{RCII}]$ and $n_{\mathrm{RCII}}, F$ critical $=2.760$, $0.05<p<0.02$ for both analyses; $F_{\text {critical }}=3.196, \mathrm{NS} \mathrm{ETR}^{\max }$ and $p=0.005>p>0.01 \mathrm{ETR}_{\text {chl } a}^{\max }$. 
volume- or of chlorophyll $a$ normalised ETRs. In general, higher values of ETR ${ }^{\max }$ were observed for tropical than subtropical provinces (Fig. 9B). However, these differences were not statistically significant. In contrast, higher values of $\mathrm{ETR}_{\mathrm{chl} a}^{\max }$ were determined for subtropical than tropical gyres (Fig. 9B). These differences between provinces clearly contrast with those observed for $\mathrm{ETR}_{\mathrm{RCII}}^{\max }$ (Table 2, Section 4.2.).

It is important to raise a word of caution about these adjusted ETRs. Firstly, considerable error is associated in assuming constant values of 0.5 and 1.0 for PSII: PSI and $\psi_{t}$ at wavelengths corresponding to peak excitation by the FRR fluorometer, respectively (Suggett et al., 2004; Moore et al., 2005). The proportion of light absorbed and subsequently transferred to PSII photochemistry has been observed to vary between ca. 0.25 and 0.60 from laboratory cultures (Suggett et al., 2004). In particular, lower values of PSII: PSI are observed for cyanobacteria than for eukaryotes since the cyanobacterial PSII typically possess pigments that are less effective at absorbing blue light (Falkowski and Raven, 1997). These observations by Suggett et al. (2004) account for variability of both PSII: PSI and $\psi_{t}$ as a result of alterations to PSII: PSI pigment loading and synthesis of pigments that alter the efficiency with which absorbed light is channelled into PSII linear electron flow. However, the relative significance of PSII: PSI versus $\psi_{\mathrm{t}}$ variability between taxa or between environmental condition is presently unknown.

Secondly, we have only data to derive PSII reaction centre concentrations from one AMT cruise. Our results indicate that province-specific components of acclimation and adaptation are driven, in part, by changes in mixed-layer depth and the light environment. Consequently, provincespecific estimates of [RCII] may also vary between the six cruises.

\subsection{Energetic coupling in subtropical and tropical Atlantic provinces}

We considered our estimates of $\mathrm{ETR}^{\max }$ and ETR $_{\text {chla }}^{\max }$ with previous observations of maximum productivity rates, $P^{\max }\left(P_{\mathrm{chl} a}^{\max }\right)$, from conventional measurements of $\mathrm{C}$ assimilation from surface waters of the tropical and subtropical Atlantic provinces (Marañón and Holligan, 1999; Marañón et al., 2000; Marañón, 2005) (Figs. 9 and 10). C-based maximum productivity rates are generally greater

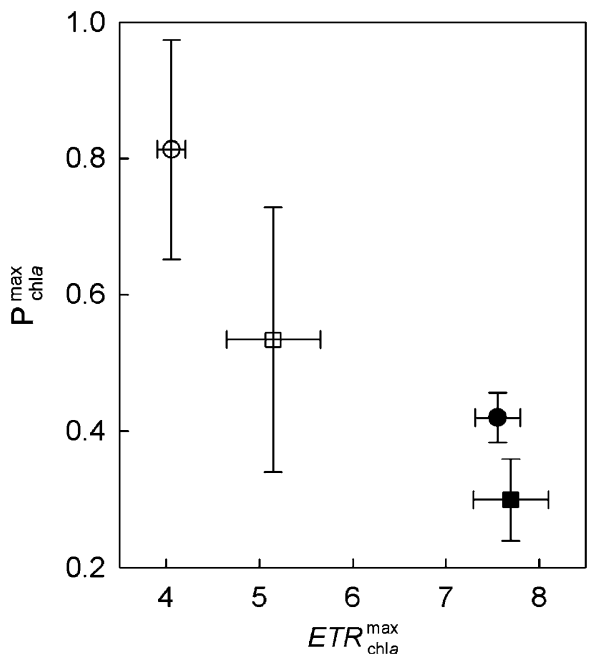

Fig. 10. Comparison of mean ( \pm standard error) maximum rates of electron turnover and carbon fixation per unit chlorophyll $a$, $\operatorname{ETR}_{\text {chla }}^{\max }\left(\operatorname{mol~e} \mathrm{mgchl}^{-} \mathrm{h}^{-1}\right)$ and $P_{\mathrm{chl} a}^{\max }\left(\operatorname{molCmgchl} a^{-1} \mathrm{~h}^{-1}\right)$, respectively, from provinces sampled during AMT 11. Symbols are as in Fig. 2.

in the tropical equatorial than in the subtropical gyres of the Atlantic by ca. 150-250\%. Furthermore, the northern subtropical gyre is on average $50-100 \%$ more productive, when expressed per unit chla, than the southern subtropical gyre. These trends of $P^{\max }\left(P_{\operatorname{chla} a}^{\max }\right)$ are consistently observed in other independent investigations based on $\mathrm{O}_{2}$ evolution (Serret et al., 2001; Robinson et al., 2002, González et al., 2002) and C assimilation (Serret et al., 2001; Teira et al., 2005; Pérez et al., 2005) measurements.

Despite the limitations in calculating [RCII] and thus of determining ETR $^{\max }$ and ETR $_{\text {chla }}^{\max }$ (Section 4.4), and any potential artefacts introduced by the data sets being collected on different cruises, distinct differences between patterns of electron turnover and of C-uptake appear to be present throughout the oligotrophic Atlantic (Figs. 9 and 10). Taken together, these independent data sets provide evidence that lower quantum requirements for $\mathrm{C}$ fixation are apparent for the tropical Atlantic (ca. 5-10 mol PSII $\mathrm{e}^{-}$: mol $\mathrm{C}$ fixed) than in the subtropical gyres (ca. $15-25 \mathrm{~mol} \mathrm{PSII}^{-}$: mol $\mathrm{C}$ fixed). Thus, the energetic requirements for photoautotrophic $\mathrm{C}$ fixation appear to be higher in subtropical than in tropical Atlantic provinces. Consequently, the degree of coupling between photochemistry and carbon fixation may not be the same for all provinces. 


\section{Summary and conclusions}

We have presented the first detailed assessment of FRR-based measurements of the photosynthetic energetic potential, as ETRs, throughout the oligotrophic environments of the Atlantic Ocean. Maximum ETRs were highly variable within and between provinces and could be partly explained by changes of light absorption in response to water column structure and light intensity. These observations were consistent with the differing taxonomic and physiological nature of phytoplankton communities from tropical and subtropical environments that has been observed previously (Marañón and Holligan, 1999; Marañón et al., 2000; Zubkov et al., 2000; Barlow et al., 2002; Marañón, 2005). However, consideration of corresponding changes of light absorption, maximum ETRs and the light saturation parameter, $E_{\mathrm{k}}$, and of differences between ETRs and previous C-based measurements of $P^{\max }$ demonstrate that photochemistry may not be tightly coupled with $\mathrm{C}$ uptake throughout these environments. Understanding this coupling is crucial for the development of bio-optical models that can accurately predict C-fixation (Morel et al., 1996; Raateoja et al., 2004). Therefore, it is clear that more attention must be directed towards the differences in coupling between ETR and C-fixation that we have observed for the vast tropical and subtropical oceanic environments.

An increasing number of FRR-based investigations demonstrate that microalgal productivity is highly variable in nature (Moore et al., 2003; Raateoja et al., 2004; Smyth et al., 2004). Our investigation reinforces recent observations that knowledge of RCII concentration is key for accurately characterising the true variability of PSII light absorption and thus calculating absolute ETRs (Suggett et al., 2003, 2004) and interpreting photophysiological processes (Suggett et al., 2004; Moore et al., 2005, 2006). As such, considerable effort must be made to quantify [RCII] in the future if we are to accurately understand the energetics that underlie carbon fixation and ultimately carbon sequestration in the world's oceans.

\section{Acknowledgements}

We thank the officers and crew of the RRS James Clark Ross for their unremitting assistance throughout Atlantic Meridional Transects 6-11. Also, we thank Nigel Rees (AMTs 7, 9) and Guy Westbrook
(AMT 8) for assisting with collection of FRR florescence data and Sam Laney for provision of FRR fluorescence processing software and yet more advice. HPLC data were kindly provided by Emilio Fernández Suárez, University of Vigo. Valuable discussion with Richard Geider greatly improved this manuscript. This study was supported by the UK Natural Environment Research Council through the Atlantic Meridional Transect consortium (NER/O/S/2001/00680). This is contribution number 123 of the AMT programme.

\section{References}

Allen, J.F., 2002. Photosynthesis of ATP- electrons, proton pumps, rotors, and poise. Cell 110, 273-276.

Avenson, T.J., Kanazawa, A., Cruz, J.A., Takizawa, K., Ettinger, W.E., Kramer, D.M., 2005. Integrating the proton circuit into photosynthesis: progress and challenges. Plant, Cell and Environment 28, 97-109.

Babin, M., Morel, A., Claustre, H., Bricaud, A., Kolber, Z., Falkowski, P.G., 1996. Nitrogen and irradiance-dependent variations in the maximum quantum yield of carbon fixation in eutrophic, mesotrophic and oligotrophic marine systems. Deep-Sea Research I 43, 1241-1272.

Badger, M.R., von Caemmerer, S., Ruuska, S., Nakano, H., 2000. Electron flow to oxygen in higher plants and algae: rates and control of direct photoreduction (Mehler Reaction) and Rubisco enzymes. Philosophical Transactions of the Royal Society of London B 355, 1433-1446.

Barlow, R.G., Aiken, J., Holligan, P.M., Cummings, D.G., Maritorena, S., Hooker, S.B., 2002. Phytoplankton pigment and absorption characteristics along meridional transects in the Atlantic Ocean. Deep Sea Research I 47, 637-660.

Behrenfeld, M.J., Kolber, Z.S., 1999. Widespread iron limitation of phytoplankton in the South Pacific Ocean. Science 283, $840-843$.

Behrenfeld, M.J., Marañón, E., Siegel, D.A., Hooker, S.B., 2002. Photoacclimation and nutrient-based model of light-saturated photosynthesis for quantifying oceanic primary production. Marine Ecology Progress Series 228, 103-117.

Behrenfeld, M.J., Prášil, O., Babin, M., Bruyant, F., 2004. In search of a physiological basis for covariations in light-limited and light-saturated photosynthesis. Journal of Phycology 40, 4-25.

Bidigare, R.R., Ondrusek, M.E., Morrow, J.H., Kiefer, D.A., 1990. In vivo absorption properties of algal pigments. SPIE 1302 (Ocean Optics X), 289-302.

Bricaud, A., Stramski, D., 1990. Spectral absorption coefficients of living phytoplankton and nonalgal biogenous matter: a comparison between the Peru upwelling area and the Sargasso Sea. Limnology and Oceanography 35, 562-582.

Bricaud, A., Claustre, H., Ras, J., Oubelkheir, K., 2004. Natural variability of phytoplankton absorption in oceanic waters: influence of the size structure of alga populations. Journal of Geophysical Research 109 Art.C11010.

Cullen, J.J., Davis, R.F., 2003. The blank can make a big difference in oceanographic measurements. Limnology and Oceanography Bulletin 12 (2), 29-35. 
Falkowski, P.G., Raven, J.A., 1997. Aquatic Photosynthesis. Blackwell, USA.

Geider, R.J., MacIntyre, H.L., 2002. Physiology and biochemistry of photosynthesis and algal carbon acquisition. In: Williams, P.J.Le.B., Thomas, D.N., Reynolds, C.S. (Eds.), Phytoplankton Productivity: Carbon Assimilation in Marine and Freshwater Ecosystems. Blackwell Science, Oxford, pp. 44-77.

González, N., Anadón, R., Marañón, E., 2002. Large-scale variability of planktonic net community metabolism in the Atlantic Ocean: importance of temporal changes in oligotrophic subtropical waters. Marine Ecology Progress Series 233, 21-30.

Gorbunov, M.Y., Kolber, Z.S., Lesser, M.P., Falkowski, P.G., 2001. Photosynthesis and photoprotection in symbiotic corals. Limnology and Oceanography, 75-85.

Hooker, S.B., Rees, N.W., Aiken, J., 2000. An objective methodology for identifying oceanographic provinces. Progress in Oceanography 45, 313-338.

Jassby, A.T., Platt, T., 1976. Mathematical formulation of the relationship between photosynthesis and light for phytoplankton. Limnology and Oceanography 21, 540-547.

Kana, T.M., 1992. Relationship between photosynthetic oxygen cycling and carbon assimilation in Synechococcus WH7803 (Cyanophyta). Journal of Phycology 28, 304-308.

Karl, D.M., Hebel, D.V., Bjorkman, K., Letelier, R.M., 1998. The role of dissolved organic matter release in the productivity of the oligotrophic North Pacific Ocean. Limnology and Oceanography 43, 1270-1286.

Kolber, Z.S., Prášil, O., Falkowski, P.G., 1998. Measurements of variable chlorophyll fluorescence using fast repetition rate techniques: defining methodology and experimental protocols. Biochimica et Biophysica Acta 1367, 88-106.

Kramer, D.M., Avenson, T.J., Edwards, G.E., 2004. Dynamic flexibility in the light reactions of photosynthesis governed by both electron and proton transfer reactions. Trends in Plant Science 9, 359-367.

Kromkamp, J.C., Forster, R.M., 2003. The use of variable fluorescence measurements in aquatic ecosystems: differences between multiple and single turnover measuring protocols and suggested terminology. European Journal of Phycology $38,103-112$.

Laney, S.R., 2003. Assessing the error in photosynthetic properties determined by fast repetition rate fluorometry. Limnology and Oceanography 48 (6), 2234-2242.

Lewitus, A.J., Kana, T.M., 1995. Light respiration in six estuarine phytoplankton species: contrasts under photoautotrophic and mixotrophic growth conditions. Journal of Phycology 31, 754-761.

Longhurst, A., Sathyendranath, S., Platt, T., Caverhill, C., 1995. An estimate of global primary production in the ocean from satellite radiometer data. Journal of Plankton Research 17, 1245-1271.

MacIntyre, H.L., Kana, T.M., Anning, T., Geider, R.J., 2002. Photoacclimation of photosynthesis irradiance response curves and photosynthetic pigments in microalgae and cyanobacteria. Journal of Phycology 38, 17-38.

Marañón, E., 2005. Phytoplankton growth rates in the Atlantic subtropical gyres. Limnology and Oceanography 50, 299-310.

Marañón, E., Holligan, P.M., 1999. Photosynthetic parameters of phytoplankton from $50^{\circ} \mathrm{N}$ to $50^{\circ} \mathrm{S}$ in the Atlantic Ocean. Marine Ecology Progress Series 176, 191-203.
Marañón, E., Holligan, P.M., Varela, M., Mouriño, B., Bale, A.J., 2000. Basin-scale variability of phytoplankton biomass, production and growth in the Atlantic Ocean. Deep-Sea Research I 47, 825-857.

Marañón, E., Behrenfeld, M.J., González, N., Mouriño, B., Zubkov, M.V., 2003. High variability of primary production in oligotrophic waters of the Atlantic Ocean: uncoupling from phytoplankton biomass and size structure. Marine Ecology Progress Series 257, 1-11.

Mauzerall, D., Greenbaum, N.L., 1989. The absolute size of a photosynthetic unit. Biochimica et Biophysica Acta 974, 119-140.

Moore, C.M., Suggett, D.J., Holligan, P.M., Sharples, J., Abraham, E.R., Lucas, M.I., Rippeth, T.P., Fisher, N.R., Simpson, J.H., Hydes, D.J., 2003. Physical controls on phytoplankton physiology and production at a shelf sea front: a fast repetition rate fluorometer based field study. Marine Ecological Progress Series 259, 29-45.

Moore, C.M., Lucas, M.I., Sanders, R., Davidson, R., 2005. Basin-scale variability of phytoplankton bio-optical characteristics in relation to bloom state and community structure in the Northeast Atlantic. Deep-Sea Research 52, 401-419.

Moore, C.M., Suggett, D.J., Hickman, A.E., Kim, Y-N., Sharples, J., Geider, R.J., Holligan, P.M., 2006. Phytoplankton photo-acclimation and photo-adaptation in response to environmental gradients in a shelf sea. Limnology and Oceanography 51 (2), 936-949.

Morel, A., Antoine, D., Babin, M., Dandonneua, Y., 1996. Measured and modeled primary production in the northeast Atlantic (EUMELI JGOFS program): the impact of natural variations in photosynthetic parameters on model predictive skill. Deep Sea Research I 43, 1273-1304.

Pérez, V., Fernández, E., Marañón, E., Serret, P., García-Soto, C., 2005. Seasonal and interannual variability of chlorophyll $a$ and primary production in the Equatorial Atlantic: in situ and remote sensing observations. Journal of Plankton Research 27, 189-197.

Prášil, O., Kolber, Z.S., Berry, J.A., Falkowski., P.G., 1996. Cyclic electron flow around photosystem II in vivo. Photosynthesis Research 48, 395-410.

Raateoja, M., Seppälä, J., Kuosa, H., 2004. Bio-optical modelling of primary production in the SW Finnish coastal zone, Baltic Sea: fast repetition rate fluorometry in case 2 waters. Marine Ecological Progress Series 267, 9-26.

Robinson, C., Serret, P., Tilstone, G., Teira, E., Zubkov, M.V., Rees, A.P., Woodward, E.M.S., 2002. Plankton respiration in the Eastern Atlantic Ocean. Deep-Sea Research 49, 787-813.

Sathyendranath, S., Longhurst, A., Caverhill, C.M., Platt, T., 1995. Regionally and seasonally differentiated primary production in the North Atlantic. Deep-Sea Research I 42, 1773-1802.

Serret, P., Robinson, C., Fernández, E., Teira, E., Tilstone, G., 2001. Latitudinal variation of the balance between phytoplankton photosynthesis and respiration in the eastern Atlantic Ocean. Limnology and Oceanography 46, 1642-1652.

Smyth, T.J., Pemberton, K.L., Aiken, J., Geider, R.J., 2004. A methodology to determine primary production and phytoplankton photosynthetic parameters from Fast Repetition Rate Fluorometry. Journal of Plankton Research 26, 1337-1350. 
Stæhr, P.A., Markager, S., Sand-Jensen, K., 2003. Pigment specific in vivo light absorption of phytoplankton from estuarine, coastal and oceanic waters. Marine Ecological Progress Series 275, 115-128.

Steglich, C., Behrenfeld, M., Koblizek, M., Claustre, C., Penno, S., Prasil, O., Partensky, F., Hess, W., 2001. Nitrogen deprivation strongly affects Photosystem II but not phycoerythrin level in the divinyl-chlorophyll b-containing cyanobacterium Prochlorococcus marinus. Biochimica et Biophysica Acta 1503, 341-349.

Suggett, D., Kraay, G., Holligan, P., Davey, M., Aiken, J., Geider, R., 2001. Assessment of photosynthesis in a spring cyanobacterial bloom by use of a fast repetition rate fluorometer. Limnology and Oceanography 46, 802-810.

Suggett, D.J., Oxborough, K., Baker, N.R., MacIntyre, H.L., Kana, T.M., Geider, R.J., 2003. Fast Repetition Rate and Pulse Amplitude Modulation chlorophyll $a$ fluorescence measurements for assessment of photosynthetic electron transport in marine phytoplankton. European Journal of Phycology 38, 371-384.

Suggett, D.J., MacIntyre, H.L., Geider, R.J., 2004. Evaluation of biophysical and optical determinations of light absorption by photosystem II in phytoplankton. Limnology and Oceanography Methods 2, 316-332.

Sukenik, A., Bennett, J., Falkowski, P.G., 1987. Light-saturated photosynthesis-limitation by electron transport or carbon fixation? Biochimica et Biophysica Acta 891, 205-215.

Teira, E., Mouriño, B., Marañón, E., Pérez, V., Pazó, M., Serret, P., de Armas, D., Escánez, J., Woodward, E.M.S., Fernández, E., 2005. Variability of chlorophyll and primary production in the Eastern North Atlantic Subtropical Gyre: potential factors affecting phytoplankton activity. Deep-Sea Research I 52, 569-588.

Varela, R.A., Figueias, F., Agustí, S., Arbones, B., 1998. Determining the contribution of pigments and the non-algal fraction to total absorption: toward a global algorithm. Limnology and Oceanography 43, 449-457.

Vincent, W.F., Neale, P.J., Richerson, P.J., 1984. Photoinhibition: algal responses to bright light during diel stratification and mixing in a tropical alpine lake. Journal of Phycology 20, 201-211.

Zubkov, M.V., Sleigh, M.A., Burkill, P.H., Leakey, R.J.G., 2000. Picoplankton community structure on the Atlantic Meridional Transect: a comparison between seasons. Progress in Oceanography 45, 369-386. 